\title{
Mineralogy and Metasomatic Evolution of Distal Strata-Bound Scheelite Skarns in the Riba de Alva Mine, Northeastern Portugal
}

\author{
L. Miguel GASPAR ${ }^{\dagger}$
}

Departamento de Geologia, Faculdade de Ciências, Universidade de Lisboa, Bloco C2, Campo Grande, 1700 Lisboa, Portugal

and Carlos M. C. Inverno

Instituto Geológico e Mineiro, Estrada da Portela-Zambujal, Apartado 7586, 2720 Alfragide, Lisboa, Portugal

\begin{abstract}
The metasediment-hosted distal scheelite skarns from the Riba de Alva mine, Barca de Alva-Escalhão region, northeastern Portugal, consist of three main levels of strata-bound, boudin-shaped, 0.5- to 4-m-thick bodies, having a total resource of 380,000 tons ( $t$ ) with an average grade of 0.51 percent $\mathrm{WO}_{3}$. The boudinage of the Cambrian metasedimentary rocks of the Slate Greywacke Complex occurred early during the Hercynian orogeny, prior to the Granitic Complex intrusion and the skarn-forming process. The Granitic Complex corresponds to reduced, highly evolved, and metallogenically specialized S-type leucogranites, comparable to those commonly associated with Mo-poor W-F skarns.

Four different skarn types were recognized: pyroxene skarn with Fe diopside \pm anorthite; amphibole-epidote skarns with actinolite + clinozoisite \pm bytownite \pm phlogopite; ore skarn with clinozoisite + scheelite + fluorite + calcite \pm labradorite \pm apatite \pm Fe axinite \pm armenite \pm scapolite; and late-stage veins with quartz (or fluorite or calcite) \pm clinozoisite \pm andesine (or albite) \pm adularia

Clinopyroxene ranges from $\mathrm{Di}_{80} \mathrm{Hd}_{20}$ to $\mathrm{Di}_{60} \mathrm{Hd}_{40}$. Amphibole compositions range from actinolite to $\mathrm{Mg}$ hornblende and are $\mathrm{F}$ rich $(0.5-1.9 \mathrm{wt} \%)$. Clinozoisite, often zoned with $\mathrm{Fe}$-poor cores, shows little compositional variation in the skarn types, having a low pistacitic component (5-13\% Ps). Plagioclase compositions grade from anorthite in pyroxene skarn through andesine and albite in late-stage veins. Phlogopite, as amphibole, is $\mathrm{F}$ rich $(2.45-4.70$ wt \%). An extremely pure Mo-free scheelite, the only ore mineral present, is restricted to the ore skarn type.

The Riba de Alva skarns were formed, after intrusion of the Hercynian Granitic Complex, by selective infiltrative metasomatic alteration of argillaceous dolomitic limestone. An early stage of prograde alteration led to the formation of the pyroxene skarn, through reaction with an Si-rich and Fe-bearing fluid. Scheelite mineralization occurred during retrograde alteration, which was mainly fracture controlled and is characterized by a pervasive infiltration metasomatism with minor diffusion in the skarn walls. This alteration started with hydration reactions to form amphibole-epidote skarns, probably under lower $\mathrm{X}_{\mathrm{CO}_{2}}$ conditions. Ore skarn formation, with scheelite deposition, took place later during this retrograde stage, mainly along veins within the stratabound boudins, as the result of a decrease in temperature and/or significant changes in the activity of some fluid components such as $\mathrm{W}, \mathrm{F}, \mathrm{Na}, \mathrm{Mn}, \mathrm{P}$, and $\mathrm{B}$, and particularly an increase in $a_{\mathrm{Ca}}$. Monomineralic late-stage veins represent the waning stage of the skarn-forming process.
\end{abstract}

\section{Introduction}

OF ALL the major skarn types (Einaudi et al., 1981), scheelite skarns are most commonly present as planar bodies, parallel either to host lithologic (strata-bound) or intrusive contacts. The stratiform appearance of such orebodies coupled with the knowledge that many strata-bound sulfide deposits are metamorphosed syngenetic has led many to question the plutonic-related model for some W skarns. Tungsten in many deposits is considered to be of a nonigneous origin, due to the absence of a known contemporaneous granitic body close to the mineralized zones, such as in the Bohemian massif (Beran et al., 1985) and the Austroalpine Crystalline Complex (Raith, 1990, 1991), both in Austria, in central-east Greenland (Hallestein and Pederson, 1983), the Bindal (Skaarup, 1974) and Bjellatind areas (Larsen, 1991) in Norway, and the Brazilian Shield (Einaudi et al., 1981). However, given the limited (if any) deep drilling in these regions, the absence of nearby granite outcrops does not rule out an igneous-related origin,

\footnotetext{
†Corresponding author: e-mail, mgaspar@fc.ul.pt
}

which a simplistic two-dimensional approach might suggest. A similar controversy concerns scheelite mineralization in the pre-Ordovician Slate (schist) Greywacke Complex in the Iberian Peninsula, where different origins were proposed. Given that an exhalative-sedimentary origin has to be excluded due to the absence of volcanic rocks interbedded in the Slate Greywacke Complex, common interpretations for this scheelite mineralization are a synsedimentary preconcentration (Arribas, 1979, 1980; Ribeiro and Pereira, 1982; Schermerhorn, 1982), as opposed to a synmetamorphic origin (Pellitero et al., 1985). According to the latter, devolatilization of sediments during metamorphism would generate a W-rich fluid that would precipitate scheelite after interaction with carbonate layers. The synsedimentary hypothesis is based on the fact that scheelite occurs at times as disseminations in these calc-silicate rocks, assuming $W$ preconcentration as scheelite paleoplacers derived through erosion of older rocks (e.g., San Pelayo orthogneiss; Arribas, 1979) or as the result of direct W precipitation (Ribeiro and Pereira, 1982). However, detailed geological and geochemical studies in those terranes 
(e.g., in the Slate Greywacke Complex: Pinto, 1985; Casquet and Tornos, 1991) have shown that those scheelite skarns are usually of magmatic origin.

This paper presents the results of a study (Gaspar, 1997; Gaspar and Inverno, 1998a) in the Riba de Alva mine, northern Portugal, one of the scheelite-mineralized systems within the Slate Greywacke Complex. The discovery of mineralization dates back to 1948 and the mine workings, both on the surface and underground, were developed in a $10 \mathrm{~km}^{2}$ area, from 1951 to 1978, with MIRAL and METAMERQUE as mine operators. According to the last report (METAMERQUE, 1976), the remaining resources (certain + probable + possible reserves) in the Riba de Alva mine were estimated to be $380,000 t$, with an average grade of 0.51 percent $\mathrm{WO}_{3}$ (range $0.1-4.0 \% \mathrm{WO}_{3}$ ), of which only ca. $2,000 \mathrm{t}$ were mined.

\section{Geologic Setting}

The Riba de Alva mine, in the Barca de Alva-Escalhão region, northeastern Portugal, occurs within the Douro Group metasediments of the Slate Greywacke Complex, locally represented by the Desejosa Formation (Fig. 1). This formation is characterized by a metamorphosed rhythmic pelite-siltite sequence with interbedded graywacke, calc-silicate rock, sparse microconglomerate, and limestone (Sousa, 1983; Silva and Ribeiro, 1994).

The main regional structure is a west-northwest-eastsoutheast isoclinal fold system, with near-horizontal axes, formed during the first Hercynian deformation phase $\left(D_{1}\right)$, developing near-vertical axial plane schistosity and boudinage of the more competent beds such as calc-silicate and graywacke rocks (Dias and Ribeiro, 1994; Silva and Ribeiro, 1994). The Riba de Alva mine itself is located within a second-order anticline on the southern limb of the main syncline. The second Hercynian deformation phase, with an associated crenulation, is not expressed in the area. The third Hercynian deformation phase $\left(D_{3}\right)$ is coaxial with $D_{1}$, developing a near-vertical crenulation and also an important ductile west-southwest-east-northeast shear zone (Silva and Ribeiro, 1994), which has mainly affected the Slate Greywacke Complex-Granitic Complex contact (Fig. 1). The area is crosscut by late Hercynian north-northeast-southsouthwest faults, subperpendicular to the main structure (Fig. 1; Silva and Ribeiro, 1994).

Regional metamorphism is predominantly greenschist facies, within the biotite zone at the mine site. The metamorphic gradient progressively increases southward, up to cordierite-K feldspar facies (Carnicero, 1982), adjacent to the Granitic Complex (Fig. 1).

The Hercynian Granitic Complex, with a whole-rock Rb/Sr age of $300 \pm 8 \mathrm{Ma}$ (Garzón and Locutura, 1981), was intruded into the core of a main $D_{1}$ anticlinal fold during $D_{3}$, which produced an associated foliation, and was also affected by a $\mathrm{D}_{3}$ ductile west-southwest-east-northeast shear zone (Fig. 1). The Granitic Complex is heterogeneous, fine to coarse grained, but all facies are reduced $\left(\mathrm{Fe}_{2} \mathrm{O}_{3} /\left(\mathrm{Fe}_{2} \mathrm{O}_{3}+\mathrm{FeO}\right)<\right.$ 0.4 ), peraluminous ( $\mathrm{ASI} \approx 1.30$; normative corundum $>4 \%$ ), highly evolved, and metallogenically specialized S-type leucogranites (Table I; Fig. 2), interpreted as resulting from

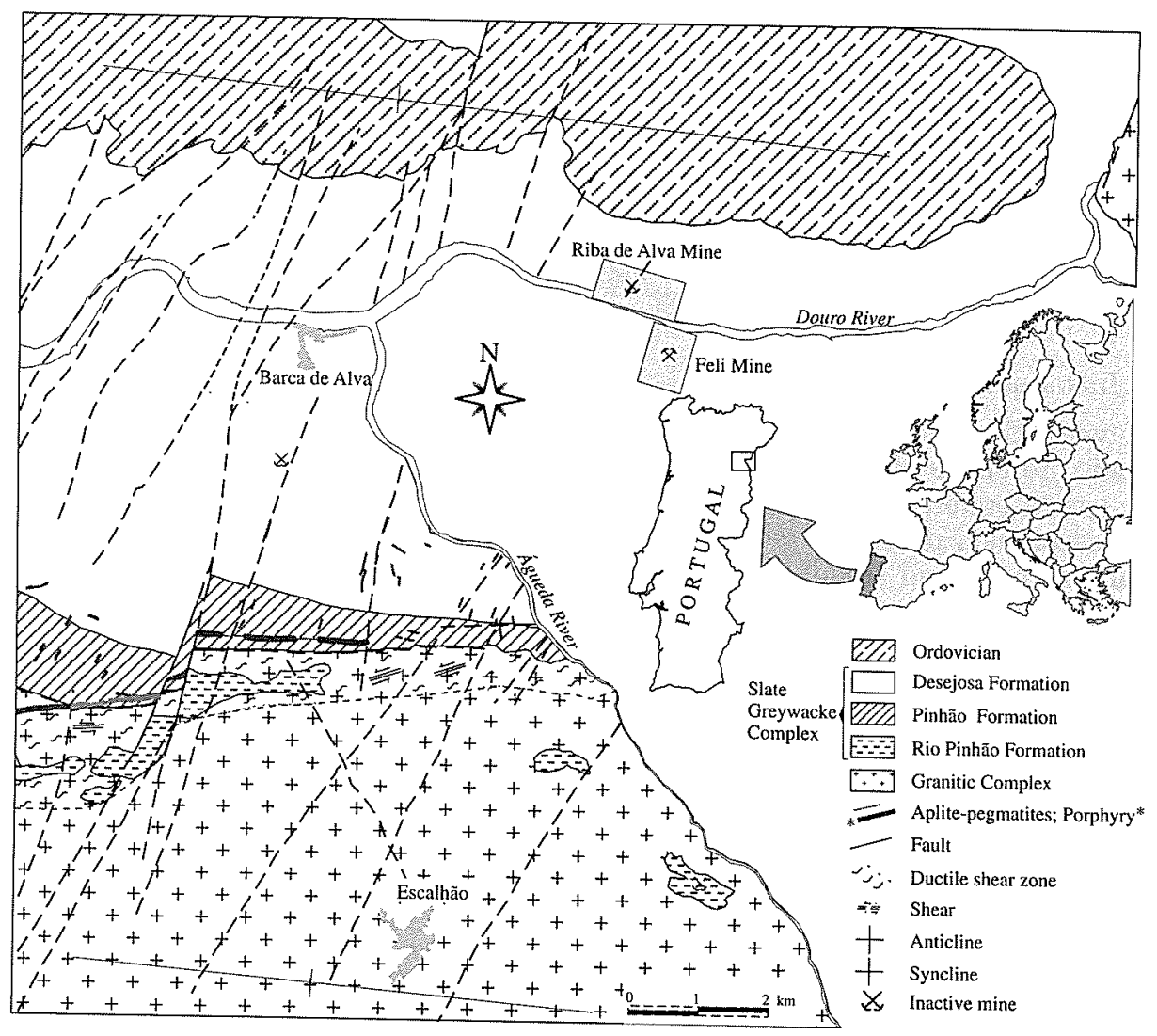

FIG. 1. Simplified geologic map of the Barca de Alva-Escalhão region (modified from Viegas, 1983; Silva et al., 1990). 
TABLE 1. Ranges for Average Compositions of the Granitic Complex Facies

\begin{tabular}{lrlr}
\hline \hline $\mathrm{SiO}_{2}$ & $72.32-73.66$ & $\mathrm{~K}_{2} \mathrm{O} / \mathrm{Na}_{2} \mathrm{O}$ & $1.57-2.01$ \\
$\mathrm{Al}_{2} \mathrm{O}_{3}$ & $14.62-14.80$ & $\left.\mathrm{Fe}_{2} \mathrm{O}_{3} / \mathrm{Fe}_{2} \mathrm{O}_{3+} \mathrm{FeO}\right)$ & $0.17-0.34$ \\
$\mathrm{~K}_{2} \mathrm{O}$ & $4.65-5.26$ & $\mathrm{~K}_{2} \mathrm{O} / \mathrm{MgO}$ & $12.05-18.77$ \\
$\mathrm{Na}_{2} \mathrm{O}$ & $2.68-2.99$ & $\mathrm{FeO}(\mathrm{t}) / \mathrm{MgO}$ & $3.55-4.84$ \\
$\mathrm{P}_{2} \mathrm{O}_{5}$ & $0.33-0.36$ & $\mathrm{ASI}$ & $1.29-1.43$ \\
$\mathrm{CaO}$ & $0.62-0.77$ & $\mathrm{Rb} / \mathrm{Sr}$ & $4.47-6.17$ \\
$\mathrm{FeO}(\mathrm{t})$ & $1.20-1.53$ & $\mathrm{Nb} / \mathrm{Zr}$ & $0.10-0.20$ \\
$\mathrm{MgO}$ & $0.13-0.43$ & $(\mathrm{Li} \times 1,000) / \mathrm{K}$ & $8.23-15.55$ \\
$\mathrm{MnO}$ & $0.03-0.04$ & $\mathrm{Rb} / \mathrm{Nb}$ & $23.47-37.42$ \\
$\mathrm{TiO}$ & $0.18-0.27$ & $\mathrm{Ba} / \mathrm{Rb}$ & $0.65-1.07$ \\
$\mathrm{Rb}$ & $296-340$ & $\mathrm{~K} / \mathrm{Rb}$ & $30.55-36.42$ \\
$\mathrm{Li}$ & $86-153$ & $\mathrm{Mg} / \mathrm{Li}$ & $12.91-27.98$ \\
$\mathrm{Cs}$ & $11-35$ & $\mathrm{Mg} / \mathrm{Ti}$ & $1.39-1.61$ \\
$\mathrm{Su}$ & $10-19$ & $\mathrm{Zr} / \mathrm{Sn}$ & $3.26-10.10$ \\
$\mathrm{Ba}$ & $177-327$ & $\mathrm{Zr} / \mathrm{TiO}$ & $0.02-0.03$ \\
$\mathrm{Sr}$ & $50-67$ & $\mathrm{~V} / \mathrm{Nb}$ & $0.26-0.77$ \\
$\mathrm{Zr}$ & $62-96$ & $\mathrm{Y} / \mathrm{Nb}$ & $0.78-1.25$ \\
$\mathrm{Y}$ & $8-12$ & $\mathrm{Sc} / \mathrm{Nb}$ & $0.12-0.25$ \\
$\mathrm{Ta}$ & $<0,5-2.4$ & $\mathrm{Ce} / \mathrm{Nb}$ & $2.01-6.88$ \\
$\mathrm{Nb}$ & $9-13$ & $\mathrm{Sr} / \mathrm{Ca}$ & 0.01 \\
$\mathrm{~W}$ & $<1$ & $\mathrm{La}(\mathrm{N}) / \mathrm{La}(\mathrm{N})$ & $22.04-39.84$ \\
$\Sigma \mathrm{REE}$ & $79.80-143.97$ & & \\
& & &
\end{tabular}

$\Sigma \mathrm{REE}=\mathrm{La}+\mathrm{Ce}+\mathrm{Nd}+\mathrm{Sm}+\mathrm{Eu}+\mathrm{Tb}+\mathrm{Yb}+\mathrm{Lu}$

Data from Gaspar (1997)

partial melting of the Slate Greywacke Complex (Gaspar, 1997; Gaspar and Inverno, 1998b and c). They are enriched in $\mathrm{P}_{2} \mathrm{O}_{5}(\approx 0.35$ wt \%), $\mathrm{Rb}, \mathrm{Li}, \mathrm{Cs}$, and $\mathrm{Sn}$ and depleted in $\mathrm{Ca}$ $\left(<1\right.$ wt \%), $\mathrm{FeO}_{(\mathrm{t})}, \mathrm{MgO}(<\mathrm{l}$ wt \%), $\mathrm{Sr}, \mathrm{Ba}, \mathrm{Zr}, \mathrm{Y}, \mathrm{V}, \mathrm{Nb}, \mathrm{W}$, and $\mathrm{B}$, relative to an average granite (Tischendorf, 1977). Their geochemical parameters lie in the range of granites associated with W skarns (Meinert, 1995; Ray et al., 1995) but particularly resemble leucogranites associated with Mo-poor W-F skarns (Newberry, 1998). A granite body akin, or even belonging, to those of the Granitic Complex was intersected at

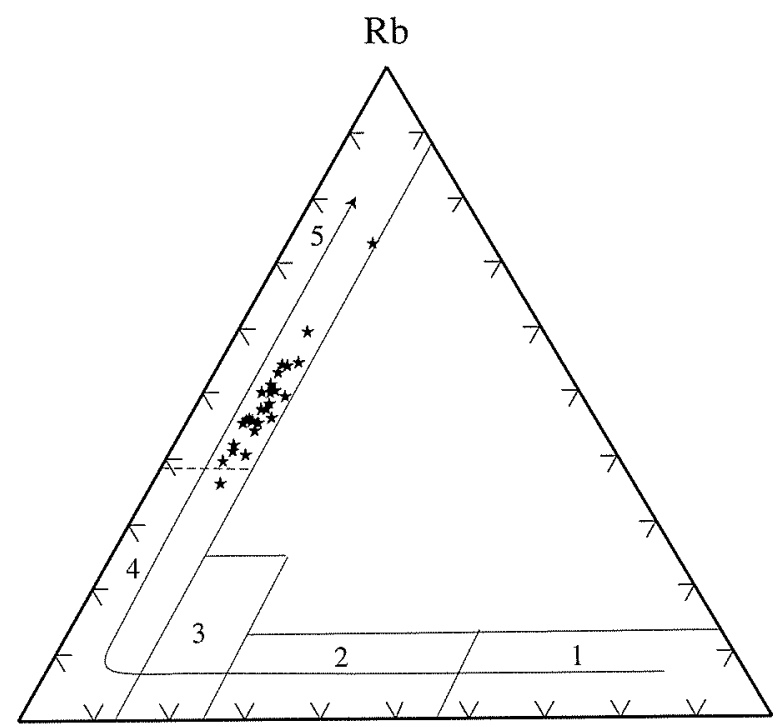

$\mathrm{Ba}$

FIG. 2. Plot of samples from the Granitic Complex in the magmatic differentiation diagram of El Bouseily and El Sokkary (1975). $1=$ diorites, $2=$ granodiorites, 3 = anomalous granites, $4=$ normal granites, $5=$ highly differentiated granites. Data from Gaspar (1997). depth in the Spanish Feli mine, very close to the Riba de Alva mine (Fig. 1; Mangas and Arribas, 1988).

A network of cassiterite-quartz veins and a zoned rare element $(\mathrm{Li}, \mathrm{P}$, and $\mathrm{Sn})$ aplite-pegmatite field occur from the Granitic Complex northward (López-Plaza et al., 1982; Roda et al., 1991, 1995), up to the Riba de Alva mine. Both ore types were mined at several locations, including the Feli mine in Spain (Fig. 1). At the Feli mine, undeformed lithium pegmatite dikes crosscut folded cassiterite-quartz stockwork veins (Mangas and Arribas, 1988). Both cassiterite-quartz veins and pegmatite dikes crosscut skarn at the Riba de Alva mine, as well as at the Feli mine where skarn occurs as small calc-silicate bodies (Mangas and Arribas, 1988). The Granitic Complex is interpreted to be the result of a diachronic partial melting process, during which successive mineralizing fluids were released to produce different types of mineralization (Gaspar, 1997; Gaspar and Inverno, 1998b and c).

\section{Skarn Morphology and Mineralogy}

Three main skarn bodies are known in the Riba de Alva mine (skarns 1, 2, and 3; Fig. 3). Skarn 3 is the most prominent; the eastern portion of which is $200 \mathrm{~m}$ long with an average thickness of $50 \mathrm{~cm}$ and the western portion over $380 \mathrm{~m}$ long with an average thickness of $2.5 \mathrm{~m}$ (locally $4.0 \mathrm{~m}$ ). Skarn 1 ranges from less than $25 \mathrm{~cm}$ to about $50 \mathrm{~cm}$ thick.

Most of the underground workings (Fig. 3) are no longer acessible, so sampling was mainly conducted from surface outcropping and from representative tailing piles.

Skarns are strata-bound lenticular bodies, dipping $80^{\circ}$ northward, and commonly boudin shaped. The boudins are interconnected along the skarn, but isolated boudins occur in the thinnest extremities (Figs. 4A-B, 5). Boudins developed during the first Hercynian deformation phase $\left(D_{1}\right)$ throughout the region (Dias and Ribeiro, 1994) and exhibit fractures related to the homoaxial third Hercynian deformation phase $\left(D_{3}\right)$. These fractures affect the strata-bound skarn bodies, particularly in the necking zones of boudins but not the wall rocks (Fig. 5).

The wall rocks are pelitic schists, with biotite + sericite + quartz + plagioclase \pm chlorite \pm tourmaline (Silva and Ribeiro, 1994). Skarn contacts with wall rocks are sharp, although sometimes a reaction skarn film $(\approx 1 \mathrm{~cm})$ has been observed (Fig. 5).

The skarn bodies are complex, heterogeneous, with no systematic internal zoning except in local fracture-controlled zones (Fig. 4C). However, four different mineral assemblages were recognized based on morphological, mineralogical, and textural characteristics.

\section{Pyroxene skarn}

Pyroxene skarn (Fig. 4C) represents less than 10 percent of the skarn. It is a pale green, granoblastic rock, composed dominantly $(>95 \%)$ of a salitic clinopyroxene (Table 2 ) and minor interstitial Ca-rich plagioclase (Fig. 6). Grain size varies from very fine $(0.05 \mathrm{~mm})$ to over $1 \mathrm{~cm}$ in prismatic aggregates, where the clinopyroxene crystals are strongly fractured and the plagioclase exhibits mechanical twinning.

Actinolite \pm clinozoisite replacing clinopyroxene or clinozoisite replacing plagioclase are common products of retrograde alteration (Fig. 6). Later alteration includes replacement 


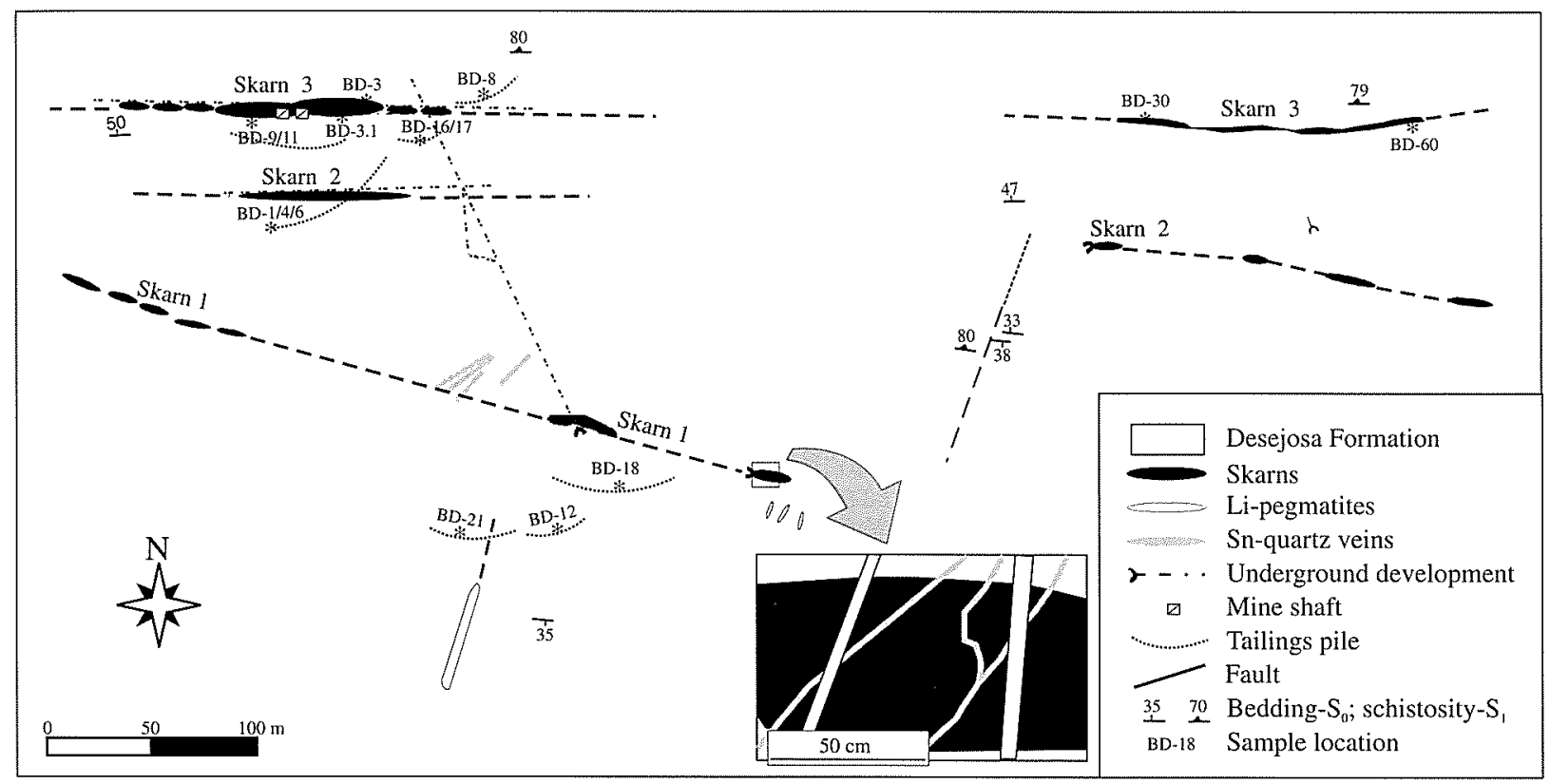

FIG. 3. Surface geologic map of the Riba de Alva mine, with superimposed underground development (modified from METAMERQUE, 1976). Zoom frame to show crosscutting relationships between skarn, cassiterite-quartz veins, and Li aplite-pegmatites. From a total of 65 skarn samples, collected on surface, underground and tailings, only samples with tabulated microprobe analytical results or used in the figures are plotted in this map.

of plagioclase by carbonate and clinopyroxene by chlorite + carbonate $\pm \mathrm{Fe}$ oxides (Fig. 6).

\section{Amphibole-epidote skarns}

Amphibole-epidote skarns comprise a dominant amphibole-rich skarn (90\%) and only locally an epidote-rich skarn $(10 \%)$, hereafter referred to as amphibole skarn and epidote skarn, respectively. Amphibole skarn is the most abundant type at the Riba de Alva mine $(\approx 60 \%)$, with a typical olivegreen color, due to the dominant actinolitic composition (Figs. 4D, 6; Table 3). The contact between pyroxene skarn and amphibole skarn is gradual. Locally there are pyroxene skarn relics (containing accessory titanite) within amphibole skarn, both in hand specimens (Fig. 4E) and thin sections. In places, amphibole skarn is fracture controlled (Figs. 4C, 5). Amphibole skarn has a granoblastic texture, ranging from fine-grained $(0.1 \mathrm{~mm})$ aggregates, particularly in thinner skarn layers, to acicular and fibrous coarse-grained $(1 \mathrm{~cm})$ aggregates.

Amphibole skarn also contains 5 to 10 percent of intergrown anhedral and zoned clinozoisite (Fig. 4D), anhedral bytownite (3-5\%), largely replaced by clinozoisite, and minor $(<1 \%)$ anhedral quartz (Fig. 6). In places, along the skarn contacts with host rocks, there is notable $(10 \%)$ development of phlogopite $(0.01-0.1 \mathrm{~mm}$ ), probably due to a bimetasomatic reaction during the skarn-forming process (reaction skarn; Fig. 5). Within this thin zone $(\approx 1 \mathrm{~cm})$, phlogopite is randomly oriented within the skarn, whereas it is parallel to the schistosity in the metapelitic host rock (Fig. 5). In the latter, phlogopite is less abundant and coarser than biotite in the unaltered metapelitic wall rock, but in the reaction skarn the total amount of phlogopite is similar to that of wall-rock biotite.
Epidote skarn is commonly a fine-grained $(0.05 \mathrm{~mm})$, lightcolored, grayish to brownish rock, which occurs as rhythmic interlayers with amphibole skarn in the thimner skam boudins (Figs. 4F, 5), as thin layers along the contacts with the hostrock schists, and rarely forming the central part of the boudin.

The texture of epidote skarn is equigranular, granoblastic to granolepidoblastic, with anhedral clinozoisite as the dominant mineral (>90\%). Phlogopite and actinolite are important accessory minerals where epidote skarns occur in the skarn wall zones (Fig. 4G), whereas quartz and bytownite occur in some boudin cores. A late extensive carbonatization overprints the clinozoisite in a few epidote skarns (Fig. 6).

\section{Ore skarn}

Scheelite-bearing (ore) skarn represents 15 to 20 percent of the Riba de Alva mine skarns. In spite of the strata-bound character of the Riba de Alva skarns, the ore skarn occurs as veins, 0.2 to $20 \mathrm{~cm}$ thick, either parallel to the boudin internal layering (Figs. $4 \mathrm{H}, 5)$ and/or along oblique shear fractures within the boudins (Figs. 4C, 5). Ore skarn-filling pods are also common. The replacement, occasionally complete, of former skarn assemblages by the ore skarn has often led to the recrystallization of phlogopite, actinolite, and clinozoisite throughout the ore skarn walls. Ore skarns are light-colored, from white to grayish, rarely greenish hues, medium- to coarse-grained $(0.5-2 \mathrm{~cm})$ granoblastic rocks.

Clinozoisite is the main mineral phase, comprising 25 to 50 percent of the rock, and occurs early in the paragenetic sequence (Fig. 6). It is present as euhedral crystals, often twinned and zoned, and occurs either disseminated or in radial prismatic aggregates where the crystals can be over $1 \mathrm{~cm}$ long (Fig. 7A-C). Clinozoisite replaces labradorite intergrown with quartz (Figs. 6, 7A). 

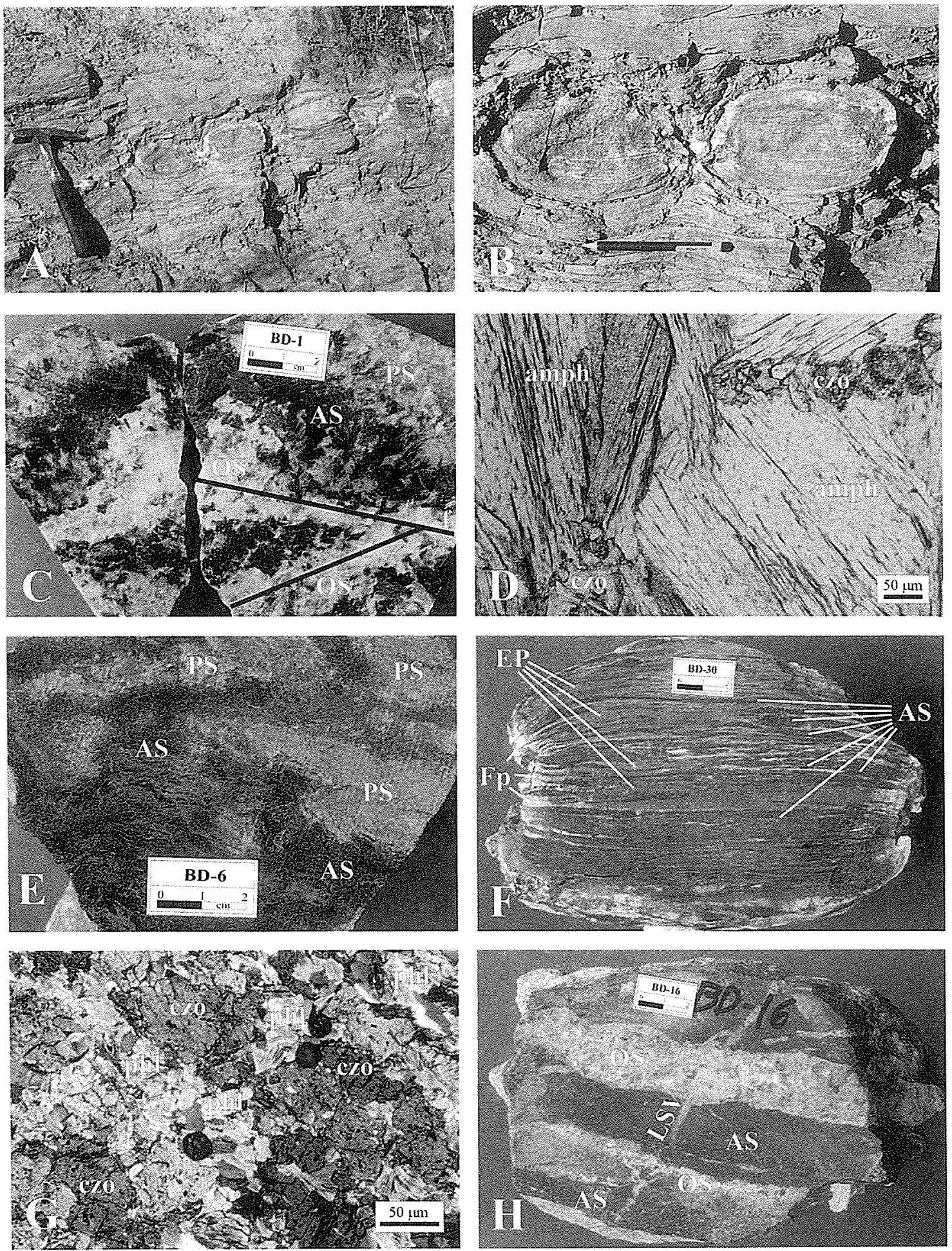

FIG. 4. A. Skam boudins in a narrow part of eastern level 3 in the Riba de Alvat mine. B. Detail of (A), where the softening of deformation in host rock around the skarn boudin is seen. Thin calc-silicate layers are also exhibited by the host rock. The boudin necking zone has a scant filling by $\mathrm{K}$ feldspar. C. Skarn zoning around a fracture ( $)$ ). Outer zones with pyroxene skam (PS), intermediate zones with amphibole skarn (AS), and central part with ore skam (OS). Sample BD-1 collected from the main tailings pile. D. Photomicrograph of amphibole skarn. Long amphibole (amph) crystals sustaining growth of small clinozoisite (czo) crystals. Plane-polarized light. Sample BD-16.1. E. Amphibole skam (AS) replacing pyroxene skarn (PS). F. Rhythmic alternation of epidote skam (EP) and amphibole skarn (AS) in a boudin. Feldspar (Fp) developed in the boudin necking zones and sometimes replaced the epiclote-rich skam layers in the boudin inner part. Eastem level 3 in the Riba de Alva mine. Sample BD-30. G. Photomicrograph of epidote-rich skam. Clinozoisite (darker) and phlogopite (lighter) crystals. Crossed polars. Sample BD-9. H. Amphibole skarn (AS) crosscut by near-horizontal ore skarn (OS). Oblique veinlets are latestage veins (LSV) with quartz + clinozoisite. Sample BD-16 collected from the main tailings pile. 

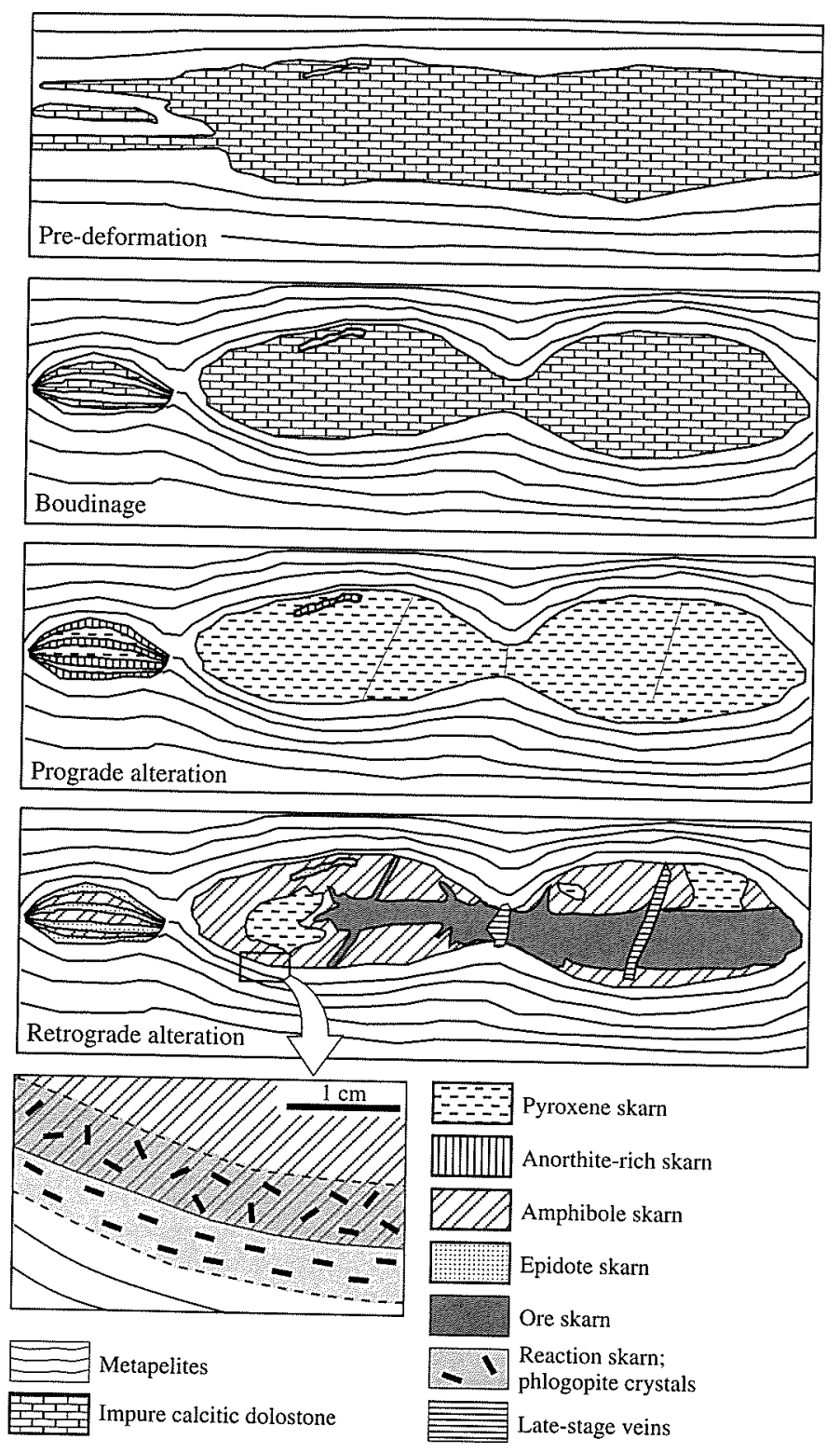

FIG. 5. Schematic morphological and typological evolution of a Riba de Alva skarn layer.

Scheelite $(<5-15 \%)$, exclusive of the ore skarn, occurs in disseminated subhedral fine- to coarse-grained $(0.01 \mathrm{~mm}$ to $>1 \mathrm{~cm}$ ), colorless to white crystals. The crystals are homogeneous, fractured, with neither zoning nor metallic mineral inclusions and are intergrown with clinozoisite (Fig. 7B-C) and/or fluorite, though they can postdate the former (Fig. 6).

Fluorite is also abundant (15-30\%) and occurs in masses, veinlets, and also disseminated as small crystals. The latest of the dominant minerals to form in the ore skarn assemblage is calcite (5-10\%; Fig. 6) that occurs as disseminated small crystals lining vugs and also either along fluorite cleavage planes or in millimetric veinlets.

Common accessory minerals (each $<1 \%$ ) are apatite, axinite, armenite, and scapolite, all commonly intergrown with clinozoisite and clearly transected by fluorite and/or calcite veinlets (Fig. 6). Apatite is in close association with scheelite,
TABLE 2. Representative Pyroxene Analyses from the Riba de Alva Mine

\begin{tabular}{lrrrrrrrr} 
& \multicolumn{3}{c}{ Pyroxene skarn } & & \multicolumn{3}{c}{ Amphibole skarn } \\
\cline { 2 - 3 } \cline { 8 - 9 } Sample & \multicolumn{1}{c}{ BD-1 } & \multicolumn{1}{c}{ BD-6 } & BD-17 & & BD-3.1 & BD-4 & BD-16 \\
\hline $\mathrm{SiO}_{2}$ & 53.19 & 53.11 & 52.94 & & 51.66 & 51.16 & 52.72 \\
$\mathrm{TiO}_{2}$ & 0.01 & 0.02 & 0.01 & & 0.03 & 0.00 & 0.00 \\
$\mathrm{Al}_{2} \mathrm{O}_{3}$ & 0.64 & 0.40 & 0.20 & & 0.49 & 1.50 & 0.23 \\
$\mathrm{P}_{2} \mathrm{O}_{5}$ & 0.02 & 0.00 & 0.03 & & 0.00 & 0.04 & 0.00 \\
$\mathrm{FeO}(\mathrm{t})$ & 6.84 & 9.06 & 8.70 & & 11.88 & 11.87 & 6.67 \\
$\mathrm{MnO}$ & 0.24 & 0.38 & 0.33 & & 0.37 & 0.44 & 0.33 \\
$\mathrm{MgO}$ & 13.73 & 12.57 & 12.71 & & 10.29 & 9.48 & 13.96 \\
$\mathrm{CaO}$ & 24.95 & 24.72 & 24.77 & & 24.32 & 23.82 & 24.93 \\
$\mathrm{Na}$ & $\mathrm{O}$ & 0.12 & 0.13 & 0.06 & & 0.05 & 0.25 & 0.06 \\
$\mathrm{~K}_{2} \mathrm{O}$ & 0.00 & 0.00 & 0.00 & & 0.00 & 0.02 & 0.01 \\
$\mathrm{Total}$ & 99.74 & 100.40 & 99.74 & & 99.11 & 98.57 & 98.90
\end{tabular}

On the basis of 6 oxygens and charge balance for 4 cations to estimate $\mathrm{Fe}^{3+}$

$\begin{array}{lllllll}\mathrm{Si}^{4+} & 1.983 & 1.986 & 1.991 & 1.987 & 1.979 & 1.980\end{array}$

$\begin{array}{lllllll}\mathrm{P}^{5+} & 0.001 & 0.000 & 0.001 & 0.000 & 0.001 & 0.000\end{array}$

$\begin{array}{lllllll}\mathrm{Al}^{3+} & 0.016 & 0.014 & 0.008 & 0.013 & 0.020 & 0.010\end{array}$

$\begin{array}{lllllll}\mathrm{Fe}^{3+} & 0.000 & 0.000 & 0.000 & 0.000 & 0.000 & 0.010\end{array}$

$\begin{array}{lllllll}\text { T total } & 2.000 & 2.000 & 2.000 & 2.000 & 2.000 & 2.000\end{array}$

$\begin{array}{lllllll}\mathrm{Al}^{3+} & 0.011 & 0.003 & 0.001 & 0.009 & 0.049 & 0.000 \\ \mathrm{Fe}^{3+} & 0.016 & 0.019 & 0.012 & 0.007 & 0.000 & 0.023\end{array}$

$\begin{array}{lllllll}\mathrm{Fe}^{3+} & 0.016 & 0.019 & 0.012 & 0.007 & 0.000 & 0.023\end{array}$

$\begin{array}{lllllll}\mathrm{Ti}^{4+} & 0.000 & 0.001 & 0.000 & 0.001 & 0.000 & 0.000 \\ \mathrm{Fe}^{2+} & 0.198 & 0.264 & 0.262 & 0.375 & 0.384 & 0.176\end{array}$

$\begin{array}{lllllll}\mathrm{Fe}^{2+} & 0.198 & 0.264 & 0.262 & 0.375 & 0.384 & 0.176 \\ \mathrm{Mg}_{+}+ & 0.763 & 0.701 & 0.712 & 0.590 & 0.547 & 0.782\end{array}$

$\begin{array}{lllllll}\mathrm{Mn}^{2+} & 0.763 & 0.701 & 0.712 & 0.590 & 0.547 & 0.782\end{array}$

$\begin{array}{lllllll}\text { Ml total } & 0.996 & 0.012 & 0.010 & 0.012 & 0.014 & 0.010\end{array}$

$\begin{array}{lllllll}\mathrm{Ca}^{2+} & 0.997 & 1.000 & 0.997 & 0.994 & 0.994 & 0.991\end{array}$

$\begin{array}{lllll}0.990 & 0.998 & 1.002 & 0.987 & 1.003 \\ 0.010 & 0.004 & 0.004 & 0.019 & 0.004\end{array}$

$\begin{array}{lllllll}\mathrm{K}^{+} & 0.000 & 0.010 & 0.004 & 0.004 & 0.019 & 0.004\end{array}$

$\begin{array}{lllllll}\text { M2 total } & 1.006 & 0.000 & 0.000 & 0.000 & 0.001 & 0.000\end{array}$

$\begin{array}{lll}1.006 & 1.007 & 1.007\end{array}$

$\begin{array}{lllllll}\mathrm{Mg} / \mathrm{Fe} & 3.85 & 2.66 & 2.72 & 1.57 & 1.42 & 4.44 \\ \mathrm{Mn} / \mathrm{Fe} & 0.04 & 0.05 & 0.04 & 0.03 & 0.04 & 0.06\end{array}$

$\begin{array}{llllll}0.04 & 0.05 & 0.04 & 0.03 & 0.04 & 0.06\end{array}$

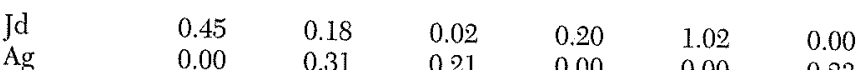

$\begin{array}{lllllll}\text { Ti Tsch } & 0.00 & 0.31 & 0.21 & 0.00 & 0.00 & 0.23\end{array}$

$\begin{array}{lllllll}\text { Fe Tsch } & 0.79 & 0.03 & 0.01 & 0.05 & 0.00 & 0.00\end{array}$

$\begin{array}{llll}0.41 & 0.35 & 0.00 & 1.00\end{array}$

$\begin{array}{llrrrrr}\text { Wo } & 49.81 & 49.71 & 50.08 & 0.24 & 1.07 & 0.00\end{array}$

$\begin{array}{lllllll}\text { En } & 39.81 & 49.71 & 50.08 & 50.19 & 49.88 & 50.04\end{array}$

$\begin{array}{llll}36.04 & 29.93 & 28.21 & 39.77\end{array}$

$\begin{array}{llllll}10.06 & 13.45 & 13.23 & 19.04 & 19.82 & 8.97\end{array}$

$\mathrm{Ag}=$ aegirine, $\mathrm{En}_{\mathrm{n}}=$ enstatite, $\mathrm{Jd}=$ jadeite, $\mathrm{Mn}=$ manganoferrosilite, $\mathrm{Tsch}$ $=$ tschermakite, $W_{0}=$ wollastonite

$\mathrm{BaO}$ and $\mathrm{SrO}$ were also analyzed but are below detection limits Calculated according to the procedure of Morimoto et al. (1988)

but the two minerals are never in contact with each other, due to the presence of calcite matrix in between. Axinite is subhedral, fractured, and strongly altered to chlorite (Fig. 7D). Armenite replaces clinozoisite, producing locally an interpenetrated pattern, with the presence of quartz and calcite in the reaction front (Fig. 7E). Scapolite occurs as anhedral crystals where factures are usually filled with fluorite.

Pyrite is a minor mineral phase $(<0.1 \%)$; other sulfides such as arsenopyrite, pyrrhotite, galena, and sphalerite, mentioned in previous studies (METAMERQUE, 1976), were not identified.

\section{Late-stage veins}

Late-stage veins are discordant, emplaced either in extensional fractures in the necking zones of the boudins (Figs. 4B, 5 ) or in shear fractures that transect all previous skarn facies 


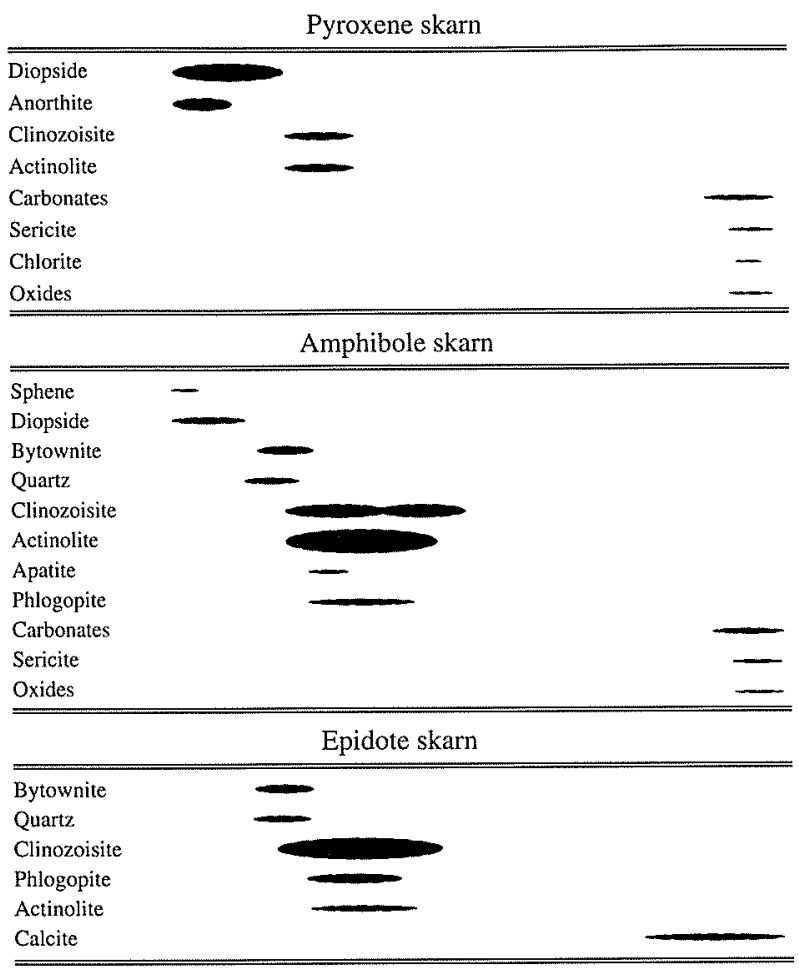

\begin{tabular}{lll}
\hline \hline Calcite & Ore skarn \\
\hline \hline Qabradorite & \\
Cuartz \\
Scapolite
\end{tabular}

\begin{tabular}{ll}
\hline \multicolumn{2}{c}{ Late-stage veins } \\
\hline Quartz \\
Fluorite \\
Calcite \\
Clinozoisite \\
Andesine + Albite \\
Adularia \\
\hline \hline Time
\end{tabular}

FIG. 6. Paragenetic sequence of the Riba de Alva mine skarn facies.

(Figs. 4H, 5). Most veins are nearly monomineralic-calcite, fluorite, or quartz-but quartz + feldspar \pm calcite veins also occur (Fig. 6). Clinozoisite may occur in euhedral, twinned, and zoned crystals, either in quartz or calcite veins (Fig. 7F). It exhibits strong alteration to margarite and calcite in the latter. The feldspars present in this assemblage include albite, mostly in the necking zones of the boudins, and andesine and adularia within the boudins (Figs. 6, 7G).
TABLE 3. Representative Amphibole Analyses from the Riba de Alva Mine

\begin{tabular}{|c|c|c|c|c|c|}
\hline \multirow[b]{2}{*}{ Sample } & \multicolumn{5}{|c|}{ Amphibole skam } \\
\hline & BD-1 & BD-3 & $\mathrm{BD}-6$ & BD-9 & BD-16.1 \\
\hline $\mathrm{SiO}_{2}$ & 50.79 & 52.43 & 49.61 & 52.28 & 48.84 \\
\hline $\mathrm{TiO}_{2}$ & 0.06 & 0.02 & 0.06 & 0.06 & 0.06 \\
\hline $\mathrm{Al}_{2} \mathrm{O}_{3}$ & 4.43 & 3.22 & 5.66 & 3.86 & 6.85 \\
\hline $\mathrm{P}_{2} \mathrm{O}_{5}$ & 0.00 & 0.00 & 0.04 & 0.03 & 0.00 \\
\hline $\mathrm{FeO}(\mathrm{t})$ & 11.92 & 11.75 & 12.96 & 11.70 & 10.38 \\
\hline $\mathrm{MnO}$ & 0.35 & 0.43 & 0.39 & 0.37 & 0.24 \\
\hline $\mathrm{MgO}$ & 14.96 & 15.42 & 14.34 & 14.57 & 14.69 \\
\hline $\mathrm{CaO}$ & 12.59 & 12.86 & 12.67 & 12.76 & 12.91 \\
\hline $\mathrm{Na}_{2} \mathrm{O}$ & 0.61 & 0.41 & 0.80 & 0.41 & 0.97 \\
\hline $\mathrm{K}_{2} \mathrm{O}$ & 0.43 & 0.28 & 0.30 & 0.28 & 0.61 \\
\hline $\mathrm{BaO}$ & 0.02 & 0.06 & 0.05 & 0.02 & 0.00 \\
\hline $\mathrm{F}$ & 1.28 & 1.92 & 1.05 & 0.48 & 1.23 \\
\hline Total & 97.45 & 98.78 & 97.92 & 96.81 & 96.78 \\
\hline
\end{tabular}

On the basis of 23 oxygens and

13 cations (except $\mathrm{Ca}, \mathrm{Na}$, and $\mathrm{K}$ ) to estimate $\mathrm{Fe}^{3+1}$

$\begin{array}{llllll}\mathrm{Si}^{4+} & 7.451 & 7.623 & 7.257 & 7.536 & 7.176\end{array}$

$\begin{array}{llllll}\mathrm{P}^{5+} & 0.000 & 0.000 & 0.005 & 0.003 & 0.000\end{array}$

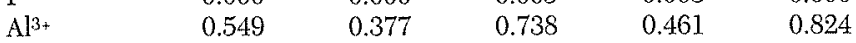

$\begin{array}{llllll}\text { T total } & 8.000 & 8.000 & 8.000 & 8.000 & 8.000\end{array}$

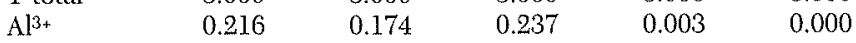

$\begin{array}{llllll}\mathrm{Fe}^{3+} & 0.108 & 0.000 & 0.238 & 0.148 & 0.000\end{array}$

$\begin{array}{llllll}\mathrm{Ti}^{4+} & 0.000 & 0.000 & 0.000 & 0.000 & 0.000\end{array}$

$\begin{array}{llllll}\mathrm{Fe}^{2+} & 0.000 & 0.000 & 0.000 & 0.000 & 0.000\end{array}$

$\begin{array}{llllll}\mathrm{Mg}^{2+} & 0.000 & 0.000 & 0.000 & 0.000 & 0.000\end{array}$

$\begin{array}{llllll}\mathrm{Mn}^{2+} & 0.000 & 0.000 & 0.000 & 0.000 & 0.000\end{array}$

$\begin{array}{llllll}\mathrm{C} \text { total } & 0.324 & 0.174 & 0.475 & 0.151 & 0.000\end{array}$

$\begin{array}{llllll}\mathrm{Ca}^{2+} & 0.000 & 0.000 & 0.000 & 0.000 & 0.000\end{array}$

$\begin{array}{llllll}\mathrm{Na}^{+} & 0.000 & 0.000 & 0.000 & 0.000 & 0.000\end{array}$

$\begin{array}{llllll}\text { B total } & 0.000 & 0.000 & 0.000 & 0.000 & 0.000\end{array}$

$\begin{array}{llllll}\mathrm{Ca}^{2+} & 0.000 & 0.000 & 0.000 & 0.000 & 0.000\end{array}$

$\begin{array}{llllll}\mathrm{Na}^{+} & 0.000 & 0.000 & 0.000 & 0.000 & 0.000\end{array}$

$\begin{array}{llllll}\mathrm{K}^{+} & 0.000 & 0.000 & 0.000 & 0.000 & 0.000\end{array}$

$\begin{array}{llllll}\mathrm{Ba}^{2+} & 0.001 & 0.003 & 0.003 & 0.001 & 0.002\end{array}$

$\begin{array}{llllll}\text { A total } & 0.001 & 0.003 & 0.003 & 0.001 & 0.002\end{array}$

$\begin{array}{llllll}\mathrm{F}^{-} & 0.000 & 0.000 & 0.000 & 0.000 & 0.000\end{array}$

SrO and $\mathrm{Cr}_{2} \mathrm{O}_{3}$ were also analyzed but are below detection limits

1 Procedure of Robinson et al. (1982)

\section{Mineral Chemistry}

\section{Analytical conditions}

Electron microprobe analyses were conducted using a CAMECA CAMEBAX at the Laboratório do Instituto Geológico e Mineiro, Portugal. Operating conditions were a $15 \mathrm{kV}$ accelerating voltage, a beam current of $20 \mathrm{nA}$ with a 5 - to $10-$ $\mu \mathrm{m}$ diam, and counting times of $20 \mathrm{~s}$. Mineral and metal (W, Mo) standards were employed; ZAF corrections were applied. Measured precision indicates an error less than 2 percent for oxides $>0.1$ wt percent.

\section{Pyroxene}

Pyroxenes from pyroxene skarn and pyroxene relics in amphibole skarn were investigated; compositions are expressed following Morimoto et al. (1988). Pyroxenes in both pyroxene and amphibole skarns display little compositional variation, except in $\mathrm{Fe} /(\mathrm{Fe}+\mathrm{Mg}$ ) ratios (Table 2; Fig. 8), ranging from $\mathrm{Hd}_{20} \mathrm{Di}_{80}$ to $\mathrm{Hd}_{40} \mathrm{Di}_{60}$. Variations in $\mathrm{Fe} /(\mathrm{Fe}+\mathrm{Mg})$ ratios in clinopyroxene could essentially reflect either protolith heterogeneities in the presence of an isochemical system or 

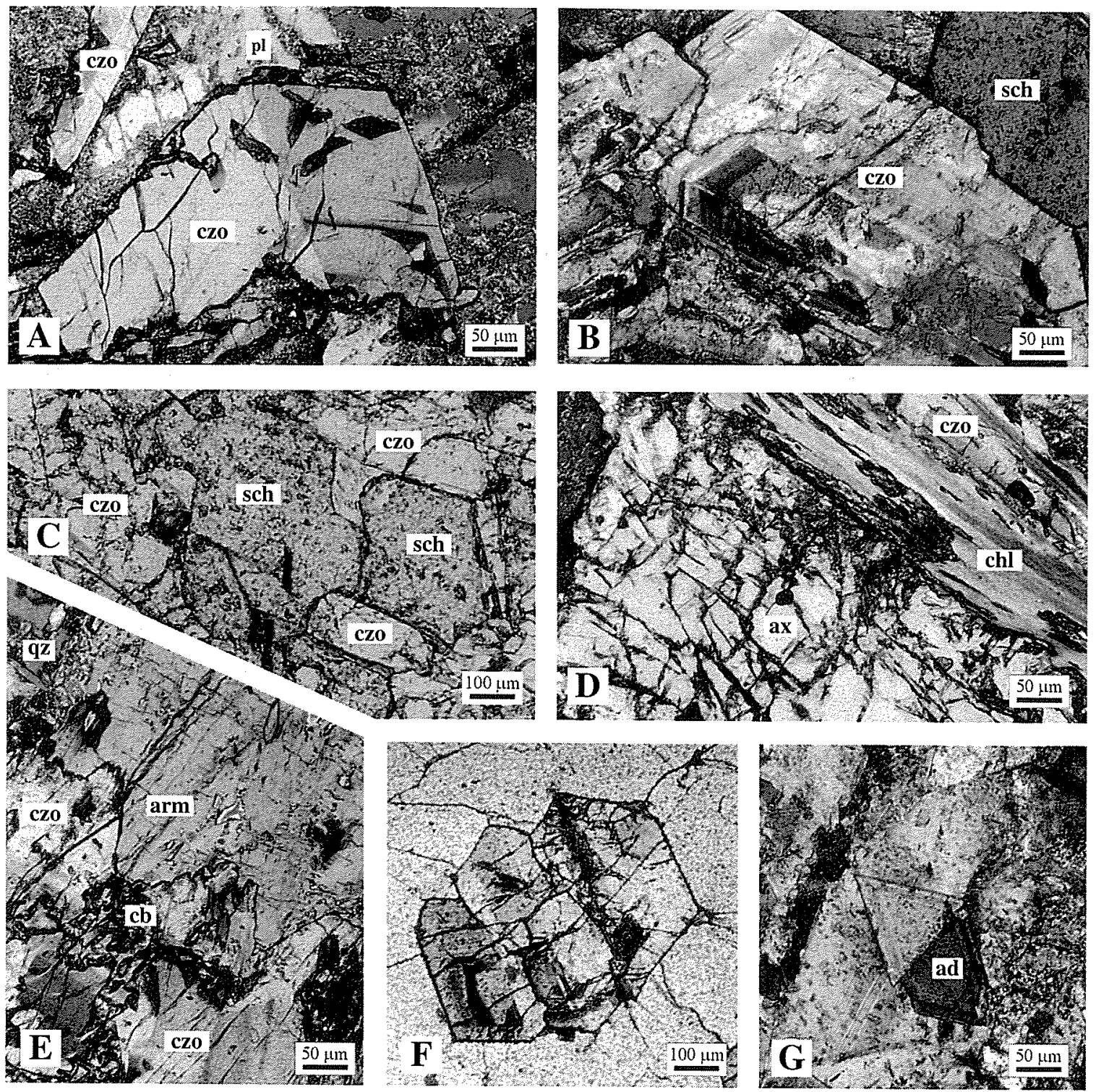

FIG. 7. A. Photomicrograph of ore skarn. Twinned and zoned clinozoisite (czo) crystals growing over plagioclase (pl). The latter exhibits sericite and carbonate alteration products. Crossed polars. Sample BD-1. B. Photomicrograph of ore skarn. Euhedral and zoned clinozoisite crystals (czo) intergrown with scheelite (sch). Crossed polars. Sample BD-16.1. C. Photomicrograph of ore skarn. Scheelite crystal (sch) with inclusions of clinozoisite (czo). Crossed polars. Sample BD-21. D. Photomicrograph of ore skarn. Highly fractured Fe axinite crystal (ax), bounded by chlorite (chl) and subhedral clinozoisite (czo). Crossed polars. Sample BD-12. E. Photomicrograph of ore skarn with clinozoisite (czo) and armenite (arm) intergrowth. Also with quartz (qz) and carbonates (cb). Crossed polars. Sample BD-12. F. Photomicrograph of late-stage veins. Euhedral, twinned, zoned clinozoisite crystal surrounded by quartz. Crossed polars. Sample BD-18. G. Photomicrograph of rhomb-shaped, twinned crystals of adularia (ad) in a quartz + feldspar + calcite late-stage vein. Crossed polars. Sample BD60

variations in the fluid $\mathrm{Fe}$ activity in an open environment. Notably Fe-rich diopside is restricted to the amphibole skarn (Fig. 8). These pyroxene compositions are typical for oxidized W skarns (Einaudi et al., 1981; Meinert, 1992) and Mo-poor W-F skarns (Newberry, 1998), and they are distinguished from magnesian skarn pyroxenes by the absence of very $\mathrm{Mg}$ rich compositions (e.g., Costabonne; Einaudi et al., 1981).

\section{Amphibole}

According to the nomenclature of Leake (1978), Riba de Alva skarn amphibole compositions range from actinolite to
Mg hornblende (Fig. 9), plotting according to the ideal pargasite-actinolite substitution vector (pargasite $=0.5$ tschermakite +1 edenite), though with a slight dominance of the tschermakitic component (Fig. 10). In 15 amphibole analyses, fluorine contents (Table 3; Fig. 11) range from 0.9 to $1.9 \mathrm{wt}$ percent $\mathrm{F}$ (one exception of 0.5 wt \%), representing 20 to 45 percent $\mathrm{F}$ substitution for $\mathrm{OH}$. Mg-rich hydrous silicate minerals, such as our amphiboles and biotites, incorporate more fluorine than $\mathrm{Fe}$ minerals, reflecting a " $\mathrm{Fe}^{2+}-\mathrm{F}$ avoidance" (Rosenberg and Foit, 1977). These fluorine values are common in W and Sn skarns and are higher than those reported 


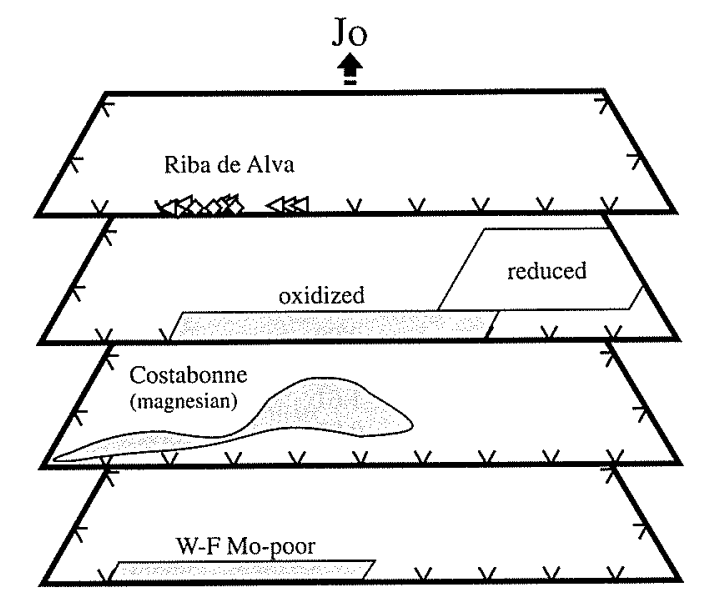

Di

$\mathrm{Hd}$

FIG. 8. Pyroxene compositions from the Riba de Alva mine skarn, compared to those from "oxidized," "reduced," and Costabonne (magnesian) W skarns (Einaudi et al., 1981) and from W-F Mo-poor skarn (Newberry, 1998). End members are Di (diopside), Hd (hedenbergite), and Jo (johannsenite).

in amphiboles from Cantung (Zaw and Clark, 1978) and Alaskan W skarns (Newberry et al., 1997), reflecting high $a_{\mathrm{F}}$ in fluid during amphibole formation.

\section{Plagioclase}

Although present in all skarn facies, only plagioclase from the amphibole skarn, ore skarn, and late-stage vein assemblages was analyzed (Table 4). Plagioclase from pyroxene skarn was optically identified as $\mathrm{An}_{90-95}$, and analyzed plagioclases plot as bytownite in the amphibole skarn, labradorite in the ore skarn, and either andesine or albite in the late-stage veins (Fig. 12), indicating a decrease in Ca content during skarn evolution.

\section{Scapolite(?)}

Physical (mainly fluorescence) and optical (uniaxial negative sign) characteristics of one of the skarn vein minerals are

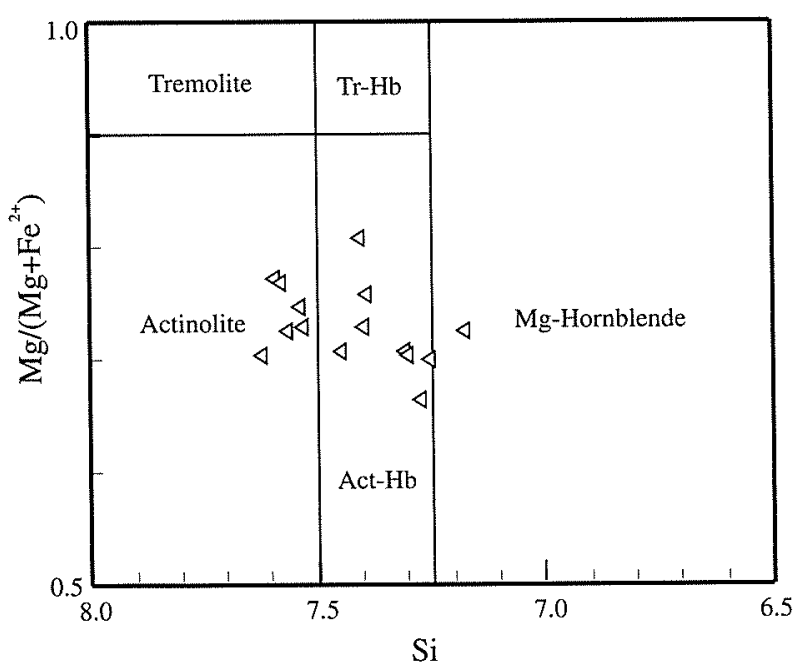

FIG. 9. Classification of the Riba de Alva mine skarn amphiboles. Field boundaries from Leake (1978).

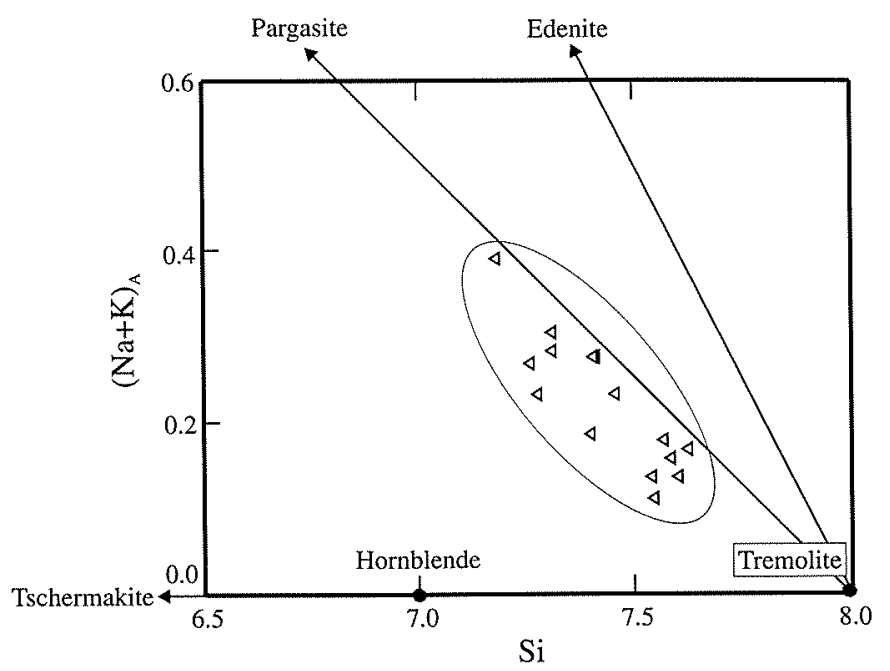

FIG. 10. $\mathrm{Si}-(\mathrm{Na}+\mathrm{K})_{\mathrm{A}}$ diagram for the Riba de Alva mine skarn amphiboles. Consider tremolite $\left(\left(\mathrm{R}^{2+}\right)_{2}\left(\mathrm{R}^{2+}\right)_{5} \mathrm{Si}_{8} \mathrm{O}_{22}(\mathrm{OH})_{2}\right)$, hornblende $\left(\left\langle\mathrm{R}^{2+}\right)_{2}\right.$ $\left.\left(\mathrm{R}_{4}^{2+}, \mathrm{R}^{3+}\right)\left(\mathrm{Si}_{7}, \mathrm{R}^{3+}\right) \mathrm{O}_{22}(\mathrm{OH})_{2}\right)$, tschermakite $\left(\left(\mathrm{R}^{2+}\right)_{2}\left(\mathrm{R}_{3}^{2+} ; \mathrm{R}_{2}^{3+}\right)\left(\mathrm{Si}_{6}, \mathrm{R}_{2}^{3+}\right) \mathrm{O}_{22}(\mathrm{OH})_{2}\right)$ edenite $\left(\mathrm{R}^{+}\left(\mathrm{R}^{2+}\right)_{2}\left(\mathrm{R}^{2+}\right)_{5}\left(\mathrm{Si}_{\bar{\gamma}}, \mathrm{R}^{3+}\right) \mathrm{O}_{22}(\mathrm{OH})_{2}\right)$, and pargasite $\left(\mathrm{R}^{+}\left(\mathrm{R}^{2+}\right)_{2}\left(\mathrm{R}^{2+}\right)_{5}\right.$ $\left.\left(\mathrm{Si}_{6}, \mathrm{R}_{2}^{3+}\right) \mathrm{O}_{22}(\mathrm{OH})_{2}\right)$.

very similar to those of Ca-rich scapolites. Their X-ray diffraction patterns show the main peaks as those of the scapolite group minerals, though the microprobe analytical data (Table 5) do not fit published scapolite compositions (e.g., Beran et al., 1985; Deer et al., 1992).

Though considering this analytical handicap, the atomic molar percentage of meionite in this mineral is very high $\left(\mathrm{Me}_{83-88}\right)$, as is usual in scapolite from W skarns and particularly from stratiform and/or strata-bound scheelite mineralizations (Beran et al., 1985; Pan, 1998).

\section{Epidote}

Clinozoisites are the only minerals present in all five skarn assemblages, which would appear to be ideal for investigation

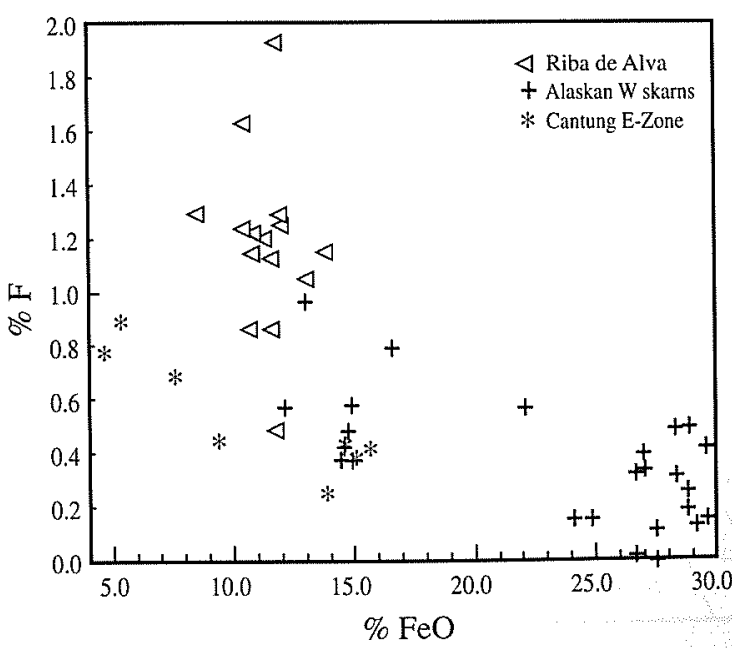

FIG. 11. F-FeO diagram for the Riba de Alva mine skarn amphiboles compared to those from the Cantung E zone (Zaw and Clark, 1978) and Alaskan W skarns (Newberry et al., 1997). 
TABLE 4. Representative Plagioclase Analyses from the Riba de Alva Mine

\begin{tabular}{|c|c|c|c|c|c|c|}
\hline \multirow[b]{2}{*}{ Sample } & \multicolumn{2}{|c|}{ Amphibole skarn } & \multicolumn{2}{|c|}{ Ore skarn } & \multicolumn{2}{|c|}{ Late-stage veins } \\
\hline & BD-4 & BD-4 & BD-12 & BD-12 & BD-11 & $\mathrm{BD}-8$ \\
\hline $\mathrm{SiO}_{2}$ & 46.87 & 49.23 & 52.30 & 54.74 & 55.79 & 66.23 \\
\hline $\mathrm{Al}_{2} \mathrm{O}_{3}$ & 33.79 & 31.40 & 29.86 & 28.38 & 27.20 & 20.18 \\
\hline $\mathrm{Fe}_{2} \mathrm{O}_{3}$ & 0.05 & 0.03 & 0.01 & 0.02 & 0.02 & 0.00 \\
\hline $\mathrm{CaO}$ & 16.65 & 14.90 & 12.93 & 10.77 & 9.35 & 0.76 \\
\hline $\mathrm{Na}_{2} \mathrm{O}$ & 2.01 & 3.13 & 4.14 & 5.27 & 6.06 & 11.09 \\
\hline $\mathrm{K}_{2} \mathrm{O}$ & 0.02 & 0.04 & 0.10 & 0.05 & 0.05 & 0.03 \\
\hline $\mathrm{SrO}$ & 0.00 & 0.00 & 0.00 & 0.29 & 0.00 & 0.00 \\
\hline Total & 99.41 & 98.78 & 99.42 & 99.52 & 98.48 & 98.28 \\
\hline \multicolumn{7}{|c|}{ On the basis of 32 oxygens } \\
\hline $\mathrm{Si}^{4+}$ & 8.652 & 9.101 & 9.543 & 9.923 & 10.165 & 11.793 \\
\hline $\mathrm{Al}^{3+}+$ & 7.351 & 6.842 & 6.422 & 6.063 & 5.842 & 4.236 \\
\hline $\mathrm{Fe}^{3+}$ & 0.007 & 0.004 & 0.001 & 0.003 & 0.003 & 0.000 \\
\hline $\mathrm{T}$ (total) & 16.003 & 15.947 & 15.965 & 15.987 & 16.008 & 16.028 \\
\hline $\mathrm{Ca}^{2+}$ & 3.294 & 2.951 & 2.528 & 2.092 & 1.825 & 0.144 \\
\hline $\mathrm{Na}^{+}$ & 0.720 & 1.123 & 1.464 & 1.852 & 2.139 & 3.827 \\
\hline $\mathrm{K}^{+}$ & 0.005 & 0.011 & 0.024 & 0.011 & 0.011 & 0.006 \\
\hline $\mathrm{Sr}^{2+}$ & 0.000 & 0.000 & 0.000 & 0.030 & 0.000 & 0.000 \\
\hline $\mathrm{M}$ (total) & 4.022 & 4.086 & 4.024 & 3.985 & 3.976 & 3.978 \\
\hline $\mathrm{Ab}(\%)$ & 17.91 & 27.50 & 36.45 & 46.83 & 53.80 & 96.22 \\
\hline $\operatorname{An}(\%)$ & 81.97 & 72.24 & 62.94 & 52.89 & 45.91 & 3.63 \\
\hline $\operatorname{Or}(\%)$ & 0.11 & 0.26 & 0.61 & 0.27 & 0.29 & 0.15 \\
\hline
\end{tabular}

$\mathrm{P}_{2} \mathrm{O}_{5}, \mathrm{TiO}_{2}, \mathrm{MgO}, \mathrm{MnO}$, and $\mathrm{BaO}$ were also analyzed but are below detection limits

of possible physical and chemical changes throughout skarn evolution, even though compositional differences are minor (Table 6; Fig.13). They are Al-rich clinozoisites, with a pistacitic component $\left(\mathrm{Ps}=\mathrm{Fe}^{3+} /\left(\mathrm{Fe}^{3+}+\mathrm{All}^{\mathrm{VI}}\right) \cdot 100\right)$ between 5 and 13 percent Ps.

In amphibole skarn, ore skarn, and late-stage vein assemblages, the clinozoisite is often zoned with $\mathrm{Fe}$-poor cores. In some of the ore skarn veins, these cores consist of zoisite with less than 5 percent $\mathrm{Ps}$. $\mathrm{Mn}, \mathrm{Ti}$, and $\mathrm{Sr}$ are common trace elements in clinozoisite, with up to 0.43 wt percent $\mathrm{TiO}_{2}$ in epidote skarns and 0.46 wt percent $\mathrm{Mn}_{2} \mathrm{O}_{3}$ and 0.92 wt percent $\mathrm{SrO}$ in ore skarns. $\mathrm{F}$ values are variable, but they can reach 0.55 wt percent $F$ (Table 6 ).

\section{Axinite}

Compared to the general chemical formula $\mathrm{Ca}_{4}(\mathrm{Fe}, \mathrm{Mg}$, $\mathrm{Mn})_{2} \mathrm{Al}_{4} \mathrm{~B}_{2} \mathrm{Si}_{8} \mathrm{O}_{30}(\mathrm{OH})_{2}$, axinites from Riba de Alva are highly aluminous (Table 7), with $\mathrm{Al}$ occupying not only its regular position but also substituting for $\mathrm{Si}$ in the tetrahedral position and for divalent cations ( $\mathrm{Fe}, \mathrm{Mg}, \mathrm{Mn}$ ). The aforementioned $\mathrm{Al}$ distribution and the presence of $\mathrm{Fe}^{3+}$ indicates an $\mathrm{Si}_{-1}$

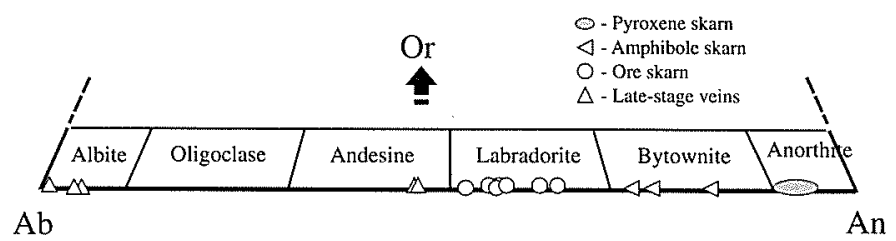

Fig. 12. Feldspars from the Riba de Alva mine skarns projected on an $\mathrm{Ab}$ (albite)-Or (orthose)-An (anorthite) diagram.
TABLE 5. Representative Scapolite Analyses from the Riba de Alva Mine

\begin{tabular}{|c|c|c|c|c|}
\hline \multirow[b]{2}{*}{ Sample } & \multicolumn{4}{|c|}{ Ore skarn } \\
\hline & BD-12 & BD-12 & BD-21 & BD-21 \\
\hline $\mathrm{SiO}_{2}$ & 48.47 & 47.81 & 48.21 & 47.45 \\
\hline $\mathrm{P}_{2} \mathrm{O}_{5}$ & 0.02 & 0.01 & 0.02 & 0.04 \\
\hline $\mathrm{Al}_{2} \mathrm{O}_{3}$ & 20.50 & 20.82 & 22.54 & 22.55 \\
\hline $\mathrm{FeO}$ & 0.00 & 0.06 & 0.07 & 0.09 \\
\hline $\mathrm{MnO}$ & 0.01 & 0.02 & 0.04 & 0.04 \\
\hline $\mathrm{CaO}$ & 19.40 & 19.86 & 19.42 & 19.10 \\
\hline $\mathrm{Na}_{2} \mathrm{O}$ & 1.91 & 1.61. & 2.15 & 2.13 \\
\hline $\mathrm{K}_{2} \mathrm{O}$ & 0.05 & 0.05 & 0.04 & 0.06 \\
\hline $\mathrm{BaO}$ & 0.03 & 0.01 & 0.00 & 0.00 \\
\hline $\mathrm{SrO}$ & 0.49 & 0.56 & & \\
\hline F & 0.00 & 0.00 & 0.08 & 0.00 \\
\hline Total & 90.88 & 90.81 & 92.58 & 91.46 \\
\hline \multicolumn{5}{|c|}{ On the basis of 12 cations $(\mathrm{Al}+\mathrm{Si}+\mathrm{P})$} \\
\hline Si4t+ & 8.006 & 7.929 & 7.736 & 7.688 \\
\hline P5+ & 0.002 & 0.001 & 0.002 & 0.005 \\
\hline $\mathrm{Al} 3+$ & 3.992 & 4.070 & 4.262 & 4.307 \\
\hline T total & 12.000 & 12.000 & 12.000 & 12.000 \\
\hline $\mathrm{Fe} 2+$ & 0.000 & 0.009 & 0.009 & 0.012 \\
\hline $\mathrm{Mn} 2+$ & 0.002 & 0.002 & 0.006 & 0.006 \\
\hline $\mathrm{Ca} 2+$ & 3.434 & 3.530 & 3.339 & 3.315 \\
\hline $\mathrm{Na}+$ & 0.610 & 0.518 & 0.669 & 0.669 \\
\hline $\mathrm{K}+$ & 0.010 & 0.010 & 0.009 & 0.013 \\
\hline $\mathrm{Sr} 2+$ & 0.047 & 0.054 & & \\
\hline $\mathrm{Ba} 2+$ & 0.002 & 0.001 & 0.000 & 0.000 \\
\hline A total & 4.105 & 4.124 & 4.033 & 4.015 \\
\hline F- & 0.000 & 0.000 & 0.040 & 0.000 \\
\hline Total charges & 51.60 & 51.65 & 51.13 & 51.05 \\
\hline
\end{tabular}

$\mathrm{TiO}_{2}, \mathrm{MgO}, \mathrm{Cl}$, and $\mathrm{S}$ were analyzed but are below 0.01 wt percent

$\mathrm{Al}_{+1}^{\mathrm{IV}} \mathrm{R}_{-1}^{2+} \mathrm{R}_{-1}^{3+}$ vector as the main substitution mechanism. The presence of $\mathrm{Mn}$ substituting for $\mathrm{Ca}$ (tinzenitic substitution) does not exceed 4 percent, having over 3 c.f.u. (cations per formula unit) $\mathrm{Ca}$, which occurs in many axinites. In spite of their high $\mathrm{Mg}$ and $\mathrm{Mn}$ contents, the Riba de Alva axinites are classified as $\mathrm{Fe}$ axinites according to Grew's terminology (1996).

\section{Armenite}

Armenite, with the chemical formula $\mathrm{Ca}_{2} \mathrm{D}_{2} \mathrm{BaAl}_{3}\left(\mathrm{Al}_{3} \mathrm{Si}_{9}\right)$ $\mathrm{O}_{30} \cdot \mathrm{H}_{2} \mathrm{O}$, where $\square$ represents a vacancy, belongs to the osumilite group (Mason, 1987). The substitution of trace elements is almost nonexistent in the Riba de Alva armenite (Table 8).

\section{Phlogopite}

Phlogopite from the wall zones of amphibole-epidote skarn have high and nearly constant $\mathrm{Mg} /(\mathrm{Mg}+\mathrm{Fe})$ ratios, 0.71 to 0.76 (Table 9; Fig. 14). The existence of vacancies in the octahedral and dodecahedral positions and the high $\mathrm{Al}$ content $\left(\mathrm{Al}^{\mathrm{IV}}+\mathrm{Al}^{\mathrm{VI}}\right)$ are deviations relative to the ideal biotite formula, annite-phlogopite (Fig. 14), which probably results from the dioctahedral deviation and tschermakitic substitution, not to mention the pyrophyllitic substitution which is also usually involved.

The $\mathrm{F}$ content is very high in these phlogopites, 2.45 to 4.70 wt percent, indicating, as discussed in amphiboles, that a fluorine-rich fluid was responsible for their formation. Other 
DISTAL STRATA-BOUND SCHEELITE SKARNS, RIBA DE ALVA MINE, NE PORTUGAL

TABLE 6. Representative Clinozoisite Analyses from the Riba de Alva Mine

\begin{tabular}{|c|c|c|c|c|c|c|c|c|c|c|c|c|c|}
\hline \multirow[b]{2}{*}{ Sample } & \multicolumn{2}{|c|}{ Pyroxene skarn } & \multicolumn{2}{|c|}{ Amphibole skarn } & \multicolumn{2}{|c|}{ Epidote skarn } & \multicolumn{5}{|c|}{ Ore skarn } & \multicolumn{2}{|c|}{ Late-stage veins } \\
\hline & BD-17 & BD-17 & BD-3 & BD-3 & BD-9 & BD-9.2 & $\begin{array}{c}\text { BD-16.1 } \\
\text { core }\end{array}$ & $\begin{array}{c}\text { BD-16.1 } \\
\text { rim }\end{array}$ & BD-21 & BD-12 & $\mathrm{BD}-12$ & $\begin{array}{l}\text { BD-18 } \\
\text { core }\end{array}$ & $\begin{array}{c}\text { BD-18 } \\
\text { rim }\end{array}$ \\
\hline $\mathrm{SiO}_{2}$ & 37.97 & 37.92 & 37.92 & 38.15 & 38.79 & 38.48 & 38.29 & 38.29 & 38.72 & 38.24 & 38.32 & 38.52 & 38.49 \\
\hline $\mathrm{P}_{2} \mathrm{O}_{5}$ & 0.00 & 0.02 & 0.02 & 0.02 & 0.00 & 0.16 & 0.03 & 0.02 & 0.03 & 0.00 & 0.09 & 0.03 & 0.03 \\
\hline $\mathrm{TiO}_{2}$ & 0.08 & 0.08 & 0.09 & 0.06 & 0.43 & 0.17 & 0.07 & 0.07 & 0.03 & 0.00 & 0.00 & 0.06 & 0.03 \\
\hline $\mathrm{Al}_{2} \mathrm{O}_{3}$ & 29.20 & 29.62 & 29.29 & 28.95 & 29.59 & 29.77 & 29.42 & 28.63 & 30.99 & 30.92 & 31.26 & 30.36 & 28.95 \\
\hline $\mathrm{Fe}_{2} \mathrm{O}_{3}(\mathrm{t})$ & 5.35 & 4.75 & 5.04 & 5.76 & 4.16 & 4.37 & 3.68 & 5.67 & 3.08 & 2.57 & 2.48 & 3.99 & 5.16 \\
\hline $\mathrm{Mn}_{2} \mathrm{O}_{3}$ & 0.07 & 0.14 & 0.17 & 0.09 & 0.06 & 0.16 & 0.28 & 0.10 & 0.46 & 0.06 & 0.27 & 0.12 & 0.13 \\
\hline $\mathrm{MgO}$ & 0.00 & 0.03 & 0.00 & 0.00 & 0.08 & 0.13 & 0.05 & 0.00 & 0.01 & 0.10 & 0.04 & 0.13 & 0.08 \\
\hline $\mathrm{CaO}$ & 24.06 & 24.15 & 24.14 & 23.83 & 24.51 & 23.65 & 23.97 & 24.40 & 24.14 & 24.00 & 23.84 & 24.22 & 24.20 \\
\hline $\mathrm{SrO}$ & 0.17 & 0.11 & 0.00 & 0.29 & & & & & & 0.66 & 0.92 & & \\
\hline$F$ & 0.09 & 0.12 & 0.00 & 0.00 & 0.02 & 0.27 & 0.06 & 0.19 & 0.25 & 0.55 & 0.03 & 0.00 & 0.00 \\
\hline Total & 96.99 & 96.94 & 96.67 & 97.15 & 97.65 & 97.15 & 95.85 & 97.36 & 97.71 & 97.11 & 97.24 & 97.43 & 97.06 \\
\hline \multicolumn{14}{|c|}{ On the basis of 12.5 oxygens } \\
\hline $\mathrm{Si}^{4+}$ & $2.970^{\circ}$ & 2.962 & 2.971 & 2.982 & 2.998 & 2.983 & 3.010 & 2.986 & 2.979 & 2.965 & 2.969 & 2.979 & 3.001 \\
\hline$P^{5+}$ & 0.000 & 0.002 & 0.002 & 0.002 & 0.000 & 0.010 & 0.002 & 0.002 & 0.002 & 0.000 & 0.006 & 0.002 & 0.002 \\
\hline $\mathrm{Al}^{3+}$ & 0.030 & 0.037 & 0.027 & 0.016 & 0.002 & 0.007 & 0.000 & 0.012 & 0.019 & 0.035 & 0.025 & 0.020 & 0.000 \\
\hline $\mathrm{T}$ total & 3.000 & 3.000 & 3.000 & 3.000 & 3.000 & 3.000 & 3.012 & 3.000 & 3.000 & 3.000 & 3.000 & 3.000 & 3.003 \\
\hline $\mathrm{Al}^{3+}$ & 2.662 & 2.690 & 2.678 & 2.651 & 2.694 & 2.714 & 2.726 & 2.619 & 2.791 & 2.790 & 2.831 & 2.748 & 2.660 \\
\hline $\mathrm{Mn}^{3+}$ & 0.005 & 0.009 & 0.011 & 0.006 & 0.004 & 0.011 & 0.019 & 0.006 & 0.030 & 0.004 & 0.017 & 0.008 & 0.008 \\
\hline $\mathrm{Fe}^{3+}$ & 0.315 & 0.279 & 0.297 & 0.339 & 0.242 & 0.255 & 0.218 & 0.333 & 0.178 & 0.150 & 0.144 & 0.232 & 0.303 \\
\hline $\mathrm{Mg}^{2+}$ & 0.000 & 0.004 & 0.000 & 0.000 & 0.010 & 0.015 & 0.005 & 0.000 & 0.001 & 0.011 & 0.004 & 0.015 & 0.009 \\
\hline $\mathrm{Ti}^{0+}$ & 0.005 & 0.005 & 0.005 & 0.003 & 0.025 & 0.010 & 0.004 & 0.004 & 0.001 & 0.000 & 0.000 & 0.003 & 0.002 \\
\hline $\mathrm{X}$ total & 2.986 & 2.987 & 2.992 & 3.000 & 2.975 & 3.004 & 2.972 & 2.962 & 3.002 & 2.955 & 2.997 & 3.007 & 2.982 \\
\hline $\mathrm{Ca}^{2+}$ & 2.017 & 2.021 & 2.027 & 1.996 & 2,030 & 1.964 & 2.019 & 2.039 & 1.990 & 1.994 & 1.979 & 2.007 & 2.022 \\
\hline $\mathrm{Sr}^{2+}$ & 0.008 & 0.005 & 0.000 & 0.013 & & & & & & 0.030 & 0.041 & & \\
\hline $\mathrm{Y}$ total & 2.024 & 2.027 & 2.030 & 2.010 & 2.030 & 1.968 & 2.020 & 2.039 & 1.990 & 2.024 & 2.021 & 2.008 & 2.030 \\
\hline $\mathrm{F}_{-}$ & 0.023 & 0.030 & 0.000 & 0.000 & 0.005 & 0.065 & 0.014 & 0.047 & 0.060 & 0.136 & 0.008 & 0.000 & 0.000 \\
\hline$\%$ Ps & 10.57 & 9.40 & 9.99 & 11.33 & 8.24 & 8.59 & 7.39 & 11.27 & 6.01 & 5.10 & 4.85 & 7.80 & 10.22 \\
\hline
\end{tabular}

$\mathrm{Na}_{2} \mathrm{O}, \mathrm{K}_{2} \mathrm{O}, \mathrm{BaO}$, and $\mathrm{Cr}_{2} \mathrm{O}_{3}$ were also analyzed but are below detection limits

important trace elements are $\mathrm{Ti}$ and $\mathrm{Ba}$, with 0.23 to $0.33 \mathrm{wt}$ percent $\mathrm{TiO}_{2}$ and 0.11 to 0.35 wt percent $\mathrm{BaO}$ (Table 9 ).

\section{Scheelite}

Scheelite from the Riba de Alva ore skarns is extremely pure, with no detectable trace elements (Table 10). This low Mo scheelite is typical of scheelite formed during retrograde alteration, in contrast to an Mo-rich scheelite formed during prograde alteration in many oxidized $W$ skarns (Einaudi et al., 1981; Kwak, 1987; Newberry, 1998).

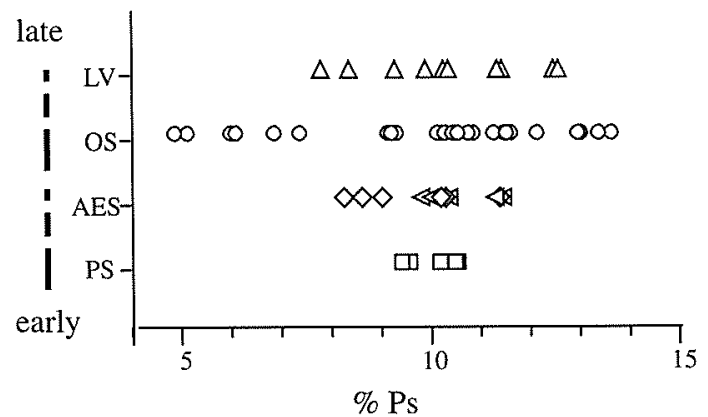

FIG. 13. Pistacitic component ( $\left.\mathrm{Ps}=\mathrm{Fe}^{3+} /\left(\mathrm{Fe}^{3+}+\mathrm{Al}^{\mathrm{VI}}\right) \cdot 100\right)$ from the Riba de Alva mine skarn clinozoisites. AES = amphibole (left triangles)epidote(lozenges) skam, OS = ore skarn, PS = pyroxene skarn, and LV = latestage veins.

\section{Skarn Evolution}

The boudinage of the skarn protolith occurred during the first Hercynian deformation phase $\left(D_{1}\right)$. A skarn-forming process took place later, after granite emplacement, because skarn minerals do not record any ductile deformation and, furthermore, in reaction skarns randomly oriented phlogopite within amphibole-epidote skarns contrasts with phlogopite parallel to $D_{1}$ schistosity in the metapelitic host rock. Retrograde alteration developed along fractures formed during $\mathrm{D}_{3}$ (coaxial with $D_{1}$ ), the same deformation phase responsible for foliation in the Granitic Complex. The skarn minerals only record this brittle deformation phase, for instance, through fractured clinopyroxene in prograde skarn and through fractured $\mathrm{Fe}$ axinite and scheelite in retrograde skarn.

The Riba de Alva skarns can be classified as distal skarns according to the classification of Kwak (1987; formed more than $500 \mathrm{~m}$ away from the granite), because they do not occur at the contact with the Granitic Complex and the nearest intrusive body was intersected at a depth of several hundred meters in the Feli mine (Fig. 1). The solidus temperature for a granitic pluton rarely exceeds $800^{\circ} \mathrm{C}$, and $500 \mathrm{~m}$ away from the intrusion a maximum contact metamorphism temperature of about $500^{\circ} \mathrm{C}$ is expected (Turner, 1981).

\section{Prograde alteration}

Tungsten skarns often occur in pelitic carbonate rocks and in interbedded carbonate-pelitic sequences, e.g., Sangdong, 
TABLE 7. Axinite Analyses from the Riba de Alva Mine

\begin{tabular}{|c|c|c|c|c|}
\hline \multirow[b]{2}{*}{ Sample } & \multicolumn{4}{|c|}{ Ore skam } \\
\hline & BD-12 & BD-12 & BD-12 & BD- 12 \\
\hline $\mathrm{SiO}_{2}$ & 40.69 & 41.52 & 41.33 & 41.07 \\
\hline $\mathrm{P}_{2} \mathrm{O}_{5}$ & 0.02 & 0.02 & 0.02 & 0.00 \\
\hline $\mathrm{Al}_{2} \mathrm{O}_{3}$ & 20.69 & 20.70 & 22.00 & 22.10 \\
\hline $\mathrm{TiO}_{2}$ & 0.10 & 0.11 & 0.07 & 0.05 \\
\hline $\mathrm{FeO}$ & 5.45 & 5.44 & 6.22 & 6.29 \\
\hline $\mathrm{MnO}$ & 3.91 & 3.87 & 2.01 & 2.13 \\
\hline $\mathrm{MgO}$ & 1.60 & 1.67 & 1.94 & 2.02 \\
\hline $\mathrm{CaO}$ & 19.22 & 19.22 & 19.42 & 19.55 \\
\hline $\mathrm{Na}_{2} \mathrm{O}$ & 0.00 & 0.02 & 0.00 & 0.01 \\
\hline $\mathrm{K}_{2} \mathrm{O}$ & 0.02 & 0.00 & 0.00 & 0.00 \\
\hline $\mathrm{F}$ & 0.16 & 0.00 & 0.41 & 0.00 \\
\hline Total & 91.86 & 92.57 & 93.41 & 93.21 \\
\hline \multicolumn{5}{|c|}{$\begin{array}{l}\text { On the basis of } 18 \text { cations, stoichiometric } \mathrm{B} \text {, and assuming a total of } 56 \\
\text { charges to fracionate } \mathrm{Fe}^{2+} / \mathrm{Fe}^{3+}\end{array}$} \\
\hline B (assumed) & 2.000 & 2.000 & 2.000 & 2.000 \\
\hline $\mathrm{T} 1$ total & 2.000 & 2.000 & 2.000 & 2.000 \\
\hline $\mathrm{Si}^{4+}$ & 7.626 & 7.706 & 7.596 & 7.528 \\
\hline $\mathrm{P}^{5+}$ & 0.003 & 0.003 & 0.003 & 0.000 \\
\hline $\mathrm{Al}^{3+}$ & 0.371 & 0.291 & 0.401 & 0.472 \\
\hline T2 total & 8.000 & 8.000 & 8.000 & 8.000 \\
\hline $\mathrm{Al}^{3+}$ & 3.986 & 3.984 & 3.991 & 3.993 \\
\hline $\mathrm{Ti}^{4+}$ & 0.014 & 0.016 & 0.009 & 0.007 \\
\hline M1 total & 4.000 & 4.000 & 4.000 & 4.000 \\
\hline $\mathrm{Al}^{3+}$ & 0.214 & 0.252 & 0.375 & 0.310 \\
\hline $\mathrm{Fe}^{3+}$ & 0.145 & 0.030 & 0.015 & 0.157 \\
\hline $\mathrm{Fe}^{2+}$ & 0.710 & 0.814 & 0.941 & 0.807 \\
\hline $\mathrm{Mn}^{2+}$ & 0.485 & 0.442 & 0.138 & 0.173 \\
\hline $\mathrm{Mg}^{2+}$ & 0.447 & 0.461 & 0.531 & 0.552 \\
\hline $\mathrm{M} 2$ total & 2.000 & 2.000 & 2.000 & 2.000 \\
\hline $\mathrm{Mn}^{2+}$ & 0.136 & 0.167 & 0.174 & 0.158 \\
\hline $\mathrm{Ca}^{2+}$ & 3.860 & 3.822 & 3.825 & 3.840 \\
\hline $\mathrm{Na}^{+}$ & 0.000 & 0.009 & 0.001 & 0.002 \\
\hline $\mathrm{K}^{+}$ & 0.004 & 0.001 & 0.000 & 0.000 \\
\hline M3 total & 4.000 & 4.000 & 4.000 & 4.000 \\
\hline F- & 0.096 & 0.000 & 0.235 & 0.000 \\
\hline
\end{tabular}

$\mathrm{SrO}$ and $\mathrm{BaO}$ were also analyzed but are below detection limits

Korea (John, 1963), Fujigatani, Japan (Sato, 1980), King Island, Tasmania (Kwak and Tan, 1981), Pine Creek, United States (Newberry, 1982), and Mactung and Cantung, Canada (Dick and Hodgson, 1982).

In Riba de Alva, the skarn protolith was never recognized due to complete replacement, but regionally similar calc-silicate rocks within the Portuguese Slate Greywacke Complex and in its Spanish equivalent are calcic-magnesian and evolved from dolomitic limestones, calcite and/or dolomite matrix metagraywacke protoliths (Pinto, 1984) or even marls (e.g., Morille, Spain; Arribas, 1980). The metagraywacke protolith is improbable in Riba de Alva, because a more complex mineralogy than that of the pyroxene skarn would be expected.

The pyroxene skarn, with an anhydrous assemblage mainly composed of $\mathrm{Fe}$ diopside \pm anorthite corresponds to an early process that modified the boudinaged protolith. This anhydrous assemblage could have been formed by thermal metamorphism and/or by an early metasomatic process. However, pyroxene from thermal metamorphism invariably shows low Fe content, usually $\mathrm{Hd}_{<25}$ (Newberry, 1982), contrasting with metasomatic pyroxenes, which range from salitic pyroxenes
TABLE 8. Armenite Analyses from the Riba de Alva Mine

\begin{tabular}{|c|c|c|c|}
\hline \multirow[b]{2}{*}{ Sample } & \multicolumn{3}{|c|}{ Ore skarn } \\
\hline & BD-12 & BD-12 & $\mathrm{BD}-12$ \\
\hline $\mathrm{SiO}_{2}$ & 47.12 & 47.21 & 47.04 \\
\hline $\mathrm{P}_{2} \mathrm{O}_{5}$ & 0.01 & 0.03 & 0.00 \\
\hline $\mathrm{Al}_{2} \mathrm{O}_{3}$ & 26.34 & 26.63 & 26.57 \\
\hline $\mathrm{TiO}_{2}$ & 0.00 & 0.00 & 0.00 \\
\hline $\mathrm{Fe}_{2} \mathrm{O}_{3}$ & 0.02 & 0.00 & 0.07 \\
\hline $\mathrm{MnO}$ & 0.00 & 0.01 & 0.02 \\
\hline $\mathrm{MgO}$ & 0.00 & 0.00 & 0.02 \\
\hline $\mathrm{CaO}$ & 9.71 & 9.58 & 9.64 \\
\hline $\mathrm{Na}_{2} \mathrm{O}$ & 0.09 & 0.03 & 0.11 \\
\hline $\mathrm{K}_{2} \mathrm{O}$ & 0.16 & 0.16 & 0.09 \\
\hline $\mathrm{BaO}$ & 12.62 & 12.41 & 12.77 \\
\hline Total & 96.06 & 96.06 & 96.32 \\
\hline \multicolumn{4}{|c|}{ On the basis of 30 oxygens } \\
\hline $\mathrm{Si}^{4+}$ & 9.039 & 9.030 & 9.003 \\
\hline $\mathrm{P}^{5+}$ & 0.001 & 0.005 & 0.000 \\
\hline $\mathrm{Al}^{3+}$ & 2.959 & 2.965 & 2.997 \\
\hline Tl total & 12.000 & 12.000 & 12.000 \\
\hline $\mathrm{Al}^{3+}$ & 2.995 & 3.040 & 2.996 \\
\hline $\mathrm{Ti}^{4+}$ & 0.000 & 0.000 & 0.000 \\
\hline $\mathrm{T} 2$ total & 2.995 & 3.040 & 2.996 \\
\hline $\mathrm{Fe}^{2+}$ & 0.003 & 0.000 & 0.011 \\
\hline $\mathrm{Mn}^{2+}$ & 0.000 & 0.002 & 0.003 \\
\hline $\mathrm{Mg}^{2+}$ & 0.000 & 0.000 & 0.006 \\
\hline $\mathrm{Ca}^{2+}$ & 1.995 & 1.963 & 1.977 \\
\hline A total & 1.998 & 1.965 & 1.995 \\
\hline $\mathrm{Ba}^{2+}$ & 0.949 & 0.930 & 0.958 \\
\hline $\mathrm{K}^{+}$ & 0.039 & 0.039 & 0.022 \\
\hline C total & 0.987 & 0.969 & 0.980 \\
\hline $\mathrm{K}^{+}$ & 0.000 & 0.000 & 0.000 \\
\hline $\mathrm{Na}^{+}$ & 0.032 & 0.012 & 0.040 \\
\hline B total & 0.032 & 0.012 & 0.040 \\
\hline
\end{tabular}

$\mathrm{SrO}$ and $\mathrm{F}$ were also analyzed but are below detection limits

$\left(\mathrm{Hd}_{20-70}\right)$ in oxidized W skarns to more hedenbergitic compositions $\left(\mathrm{Hd}_{60-90}\right)$ in reduced W skarns (Einaudi et al., 1981). Salitic pyroxenes are also typical of metasomatic pyroxenes formed either in magnesian skarns (Einaudi et al., 1981; Meinert, 1992) or in Mo-poor W-F skarns ( $\mathrm{Hd}_{10-50}$; Newberry, 1998). The latter are closest to Riba de Alva skarns, where (andraditic) garnet is absent, epidote has a low Ps component, and minimal pyrite and $\mathrm{Fe}$ oxides are present.

Formation of diopside, even considering the $\mathrm{Mg} / \mathrm{Fe}$ partition in the system, can occur directly from dolomite or involving intermediate formation of talc and/or tremolite (Fig. 15). No talc was found in Riba de Alva skarns and pyroxene consistently precedes amphibole (Fig. 6) as textural evidence indicates. If any of those intermediate minerals did actually form during prograde alteration, they might have been totally consumed. Following Bowman (1998), this is true if there was an excess of silica in the system, and if its bulk composition, expressed in the $\mathrm{MgO}-\mathrm{CaO}-\mathrm{SiO}_{2}$ composition diagram, lies in the diopside-quartz-calcite triangle (Fig. 15). Since Riba de Alva pyroxene skam is essentially made of pyroxene, the bulk composition of the system must plot close to diopside in that triangle.

Therefore, pyroxene skarn must have been formed through metasomatism by reaction of an Si-rich and Fe-bearing fluid with a Ca-Mg-bearing rock. The absence of other typical 
TABLE 9. Representative Phlogopite Analyses from the Riba de Alva Mine

\begin{tabular}{|c|c|c|c|c|c|c|}
\hline \multirow[b]{2}{*}{ Amostra } & \multicolumn{3}{|c|}{ Amplibole skarn } & \multicolumn{3}{|c|}{ Epidote skam } \\
\hline & $\mathrm{BD}-1$ & BD-3 & BD-9 & $\mathrm{BD}-6$ & BD-6 & BD-6 \\
\hline $\mathrm{SiO}_{2}$ & 39.87 & 39.92 & 39.65 & 40.37 & 39.66 & 39.58 \\
\hline $\mathrm{P}_{2} \mathrm{O}_{5}$ & 0.04 & 0.01 & 0.00 & 0.01 & 0.02 & 0.00 \\
\hline $\mathrm{TiO}_{2}$ & 0.23 & 0.23 & 0.26 & 0.29 & 0.33 & 0.27 \\
\hline $\mathrm{Al}_{2} \mathrm{O}_{3}$ & 13.39 & 13.25 & 14.34 & 13.47 & 13.62 & 13.76 \\
\hline $\mathrm{FeO}$ & 10.27 & 11.37 & 11.72 & 11.44 & 11.48 & 11.65 \\
\hline $\mathrm{MgO}$ & 18.33 & 18.06 & 16.25 & 18.46 & 18.02 & 17.81 \\
\hline $\mathrm{MnO}$ & 0.21 & 0.28 & 0.20 & 0.20 & 0.22 & 0.23 \\
\hline $\mathrm{CaO}$ & 0.02 & 0.00 & 0.00 & 0.01 & 0.03 & 0.00 \\
\hline $\mathrm{Na}_{2} \mathrm{O}$ & 0.09 & 0.08 & 0.03 & 0.05 & 0.02 & 0.06 \\
\hline $\mathrm{K}_{2} \ddot{\mathrm{O}}$ & 9.01 & 7.98 & 8.20 & 7.06 & 6.98 & 6.94 \\
\hline $\mathrm{BaO}$ & 0.23 & 0.11 & 0.20 & 0.35 & 0.23 & 0.24 \\
\hline $\mathrm{F}$ & 3.78 & 3.96 & 2.45 & 4.70 & 3.31 & 4.16 \\
\hline Total & 95.48 & 95.24 & 93.30 & 96.42 & 93.93 & 94.69 \\
\hline \multicolumn{7}{|c|}{ On the basis of 22 oxygens } \\
\hline $\mathrm{Si}^{4+}$ & 5.776 & 5.787 & 5.876 & 5.752 & 5.801 & 5.746 \\
\hline $\mathrm{p}^{5+}$ & 0.005 & 0.001 & 0.000 & 0.001 & 0.002 & 0.000 \\
\hline $\mathrm{Al}^{3+}$ & 2.219 & 2.212 & 2.124 & 2.247 & 2.197 & 2.254 \\
\hline $\mathrm{T}$ total & 8.000 & 8.000 & 8.000 & 8.000 & 8.000 & 8.000 \\
\hline $\mathrm{Al}^{3+}$ & 0.067 & 0.052 & 0.381 & 0.015 & 0.150 & 0.100 \\
\hline $\mathrm{Ti}^{4+}$ & 0.025 & 0.025 & 0.028 & 0.031 & 0.037 & 0.030 \\
\hline $\mathrm{Fe}^{2+}$ & 1.244 & 1.379 & 1.452 & 1.363 & 1.404 & 1.415 \\
\hline $\mathrm{Mg}^{2+}$ & 3.957 & 3.902 & 3.591 & 3.921 & 3.929 & 3.854 \\
\hline $\mathrm{Mn}^{2+}$ & 0.026 & 0.034 & 0.025 & 0.024 & 0.027 & 0.028 \\
\hline M total & 5.321 & 5.392 & 5.478 & 5.356 & 5.547 & 5.427 \\
\hline $\mathrm{Ca}^{2+}$ & 0.003 & 0.000 & 0.000 & 0.002 & 0.005 & 0.000 \\
\hline $\mathrm{Na}^{+}$ & 0.024 & 0.023 & 0.008 & 0.015 & 0.006 & 0.018 \\
\hline $\mathrm{K}^{+}$ & 1.666 & 1.475 & 1.550 & 1.283 & 1.303 & 1.285 \\
\hline $\mathrm{Ba}^{2+}$ & 0.013 & 0.006 & 0.011 & 0.020 & 0.013 & 0.014 \\
\hline A total & 1.705 & 1.505 & 1.569 & 1.319 & 1.327 & 1.316 \\
\hline $\mathrm{F}^{-}$ & 1.734 & 1.816 & 1.149 & 2.116 & 1.532 & 1.912 \\
\hline $\mathrm{Mg} /(\mathrm{Mg}+\mathrm{Fe})$ & 0.761 & 0.739 & 0.712 & 0.742 & 0.737 & 0.731 \\
\hline
\end{tabular}

SrO was also analyzed but is below detection limit

prograde alteration skarn minerals, such as garnet, wollastonite, and forsterite (Einaudi et al., 1981), might essentially reflect an inappropriate bulk composition.

\section{Retrograde alteration}

Skarn retrograde alteration started with hydration reactions to form actinolite and clinozoisite, the main minerals of amphibole and epidote skarns, respectively.

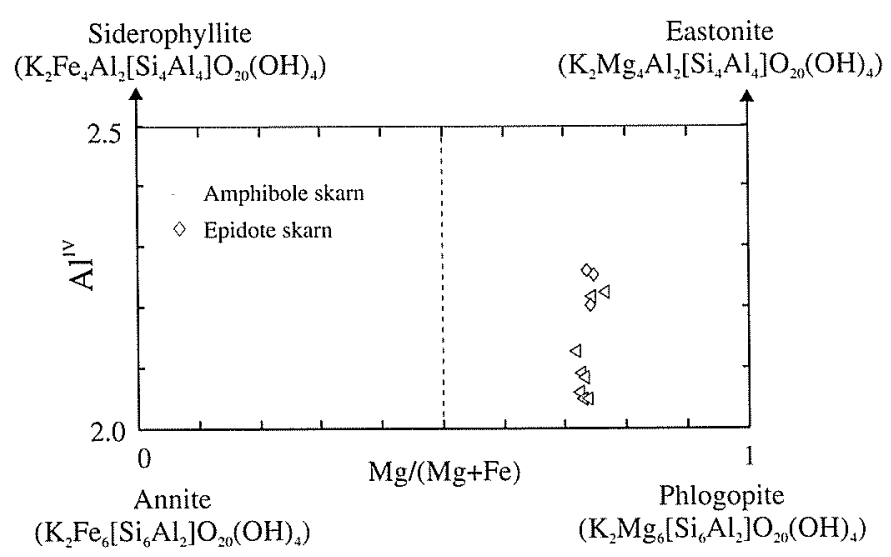

FrG. 14. Riba de Alva mine phlogopites from wall zone reaction skarn projected on the ideal component diagram of Guidotti (1984).
TABLE 10. Representative Scheelite Analyses from the Riba de Alva Mine

\begin{tabular}{|c|c|c|c|c|c|c|}
\hline \multirow[b]{2}{*}{ Sample } & \multicolumn{6}{|c|}{ Ore skam } \\
\hline & $B D-21$ & BD-21 & BD- 18 & BD-18 & BD- 16.1 & BD-16.1 \\
\hline $\mathrm{WO}_{3}$ & 80.33 & 80.41 & 79.43 & 79.32 & 79.54 & 79.56 \\
\hline $\mathrm{CaO}$ & 19.55 & 19.51 & 19.91 & 20.11 & 19.56 & 19.53 \\
\hline $\mathrm{Fe}_{2} \mathrm{O}_{3}$ & 0.03 & 0.00 & 0.04 & 0.00 & 0.00 & 0.01 \\
\hline $\mathrm{MoO}_{3}$ & 0.00 & 0.00 & 0.00 & 0.00 & 0.00 & 0.00 \\
\hline $\mathrm{MgO}$ & 0.00 & 0.00 & 0.00 & 0.00 & 0.00 & 0.00 \\
\hline $\mathrm{PbO}$ & 0.00 & 0.00 & 0.07 & 0.00 & 0.00 & 0.00 \\
\hline Total & 99.91 & 99.92 & 99.45 & 99.43 & 99.10 & 99.10 \\
\hline \multicolumn{7}{|c|}{ On the basis of 4 oxygens } \\
\hline $\mathrm{W}^{6+}$ & 0.998 & 0.999 & 0.990 & 0.988 & 0.996 & 0.996 \\
\hline $\mathrm{Mo}^{6+}$ & 0.000 & 0.000 & 0.000 & 0.000 & 0.000 & 0.000 \\
\hline $\mathrm{Fe}^{3+}$ & 0.001 & 0.000 & 0.001 & 0.000 & 0.000 & 0.000 \\
\hline $\mathrm{Ca}^{2+}$ & 1.004 & 1.002 & 1.026 & 1.036 & 1.012 & 1.011 \\
\hline $\mathrm{Mg}^{2+}$ & 0.000 & 0.000 & 0.000 & 0.000 & 0.000 & 0.000 \\
\hline $\mathrm{Pb}^{2+}$ & 0.000 & 0.000 & 0.001 & 0.000 & 0.000 & 0.000 \\
\hline Total & 2.003 & 2.002 & 2.019 & 2.024 & 2.008 & 2.007 \\
\hline
\end{tabular}

The pervasive, massive alteration of former pyroxene skarn into amphibole skam, together with chemical, textural, and fracture-controlled characteristics of the latter indicate the predominance of infiltration processes.

This alteration of $\mathrm{Fe}$ diopside to actinolite releases $\mathrm{Ca}$, and since amphibole skarn is calcite free, it follows that $\mathrm{Ca}$ would go into the fluid phase. The absence of carbonates is consistent with a decrease in $\mathrm{X}_{\mathrm{CO}_{2}}$, from the prograde to the retrograde stage in an open system, where infiltration of large amounts of $\mathrm{H}_{2} \mathrm{O}$-rich fluids occur and from where $\mathrm{CO}_{2}$ could easily flush out. Also, clinozoisite would be stable over anorthite plagioclase at very low $\mathrm{X}_{\mathrm{CO}_{2}}$. A relatively elevated fluorine activity in this $\mathrm{H}_{2} \mathrm{O}$-rich fluid is also consistent with the F-rich composition of actinolite and with the later precipitation of fluorite due to an increase in Ca activity.

The rhythmically banded amphibole-epidote skarn, as seen in the terminal portions of some thin strata-bound skarn layers (Fig. 4F), suggests a contemporaneous retrograde alteration of banded Fe diopside- and anorthite-rich skams, respectively, these last two formed, during prograde stage, from original interbedded carbonate and pelite rocks (Fig. 5).

At the contact with wall metapelites, fluid-enhanced bimetasomatic diffusion would have been the dominant chemical exchange process, developing a thin reaction skarn, characterized by the presence of phlogopite. In the reaction skarn zone (Fig. 5), phlogopitization occurred under high fluid $a_{\mathrm{Mg}}, a_{\mathrm{F}}$, and $a_{\mathrm{K}}$, where the sources for $\mathrm{Mg}$ and $\mathrm{K}$ were the $\mathrm{Mg}$-bearing minerals from the skam and the biotite from the wall rock, respectively. In fact, the abundance of biotite in the unaltered metapelitic wall rock is similar to the total phlogopite (phlogopite in altered metapelitic rock plus phlogopite within the calc-silicate rock) of the reaction skarn.

After amphibole skarn formation, with the consequent increase in $a_{\mathrm{Ca}}$ and/or possible lowering of temperature, scheelite precipitates together with the other ore skarn minerals, clinozoisite + fluorite + calcite \pm labradorite \pm quartz $\pm \mathrm{Fe}$ axinite \pm scapolite \pm apatite \pm armenite, mainly in the fracturecontrolled ore skarn within the strata-bound skarn (Fig. 5). 


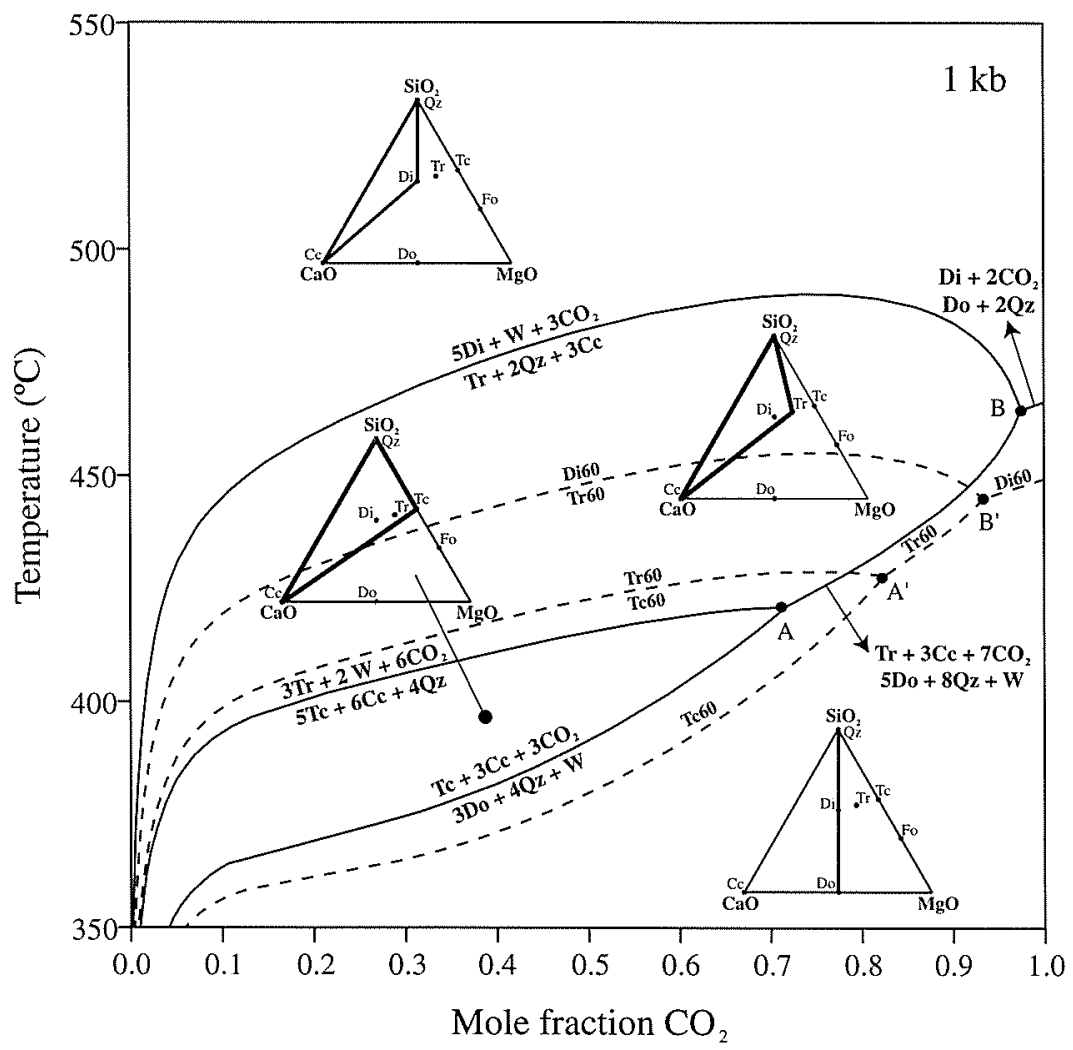

FrG. 15. Isobaric ( $\mathrm{P}=1 \mathrm{kbar}$ ) $\mathrm{T}-\mathrm{X}_{\mathrm{CO}_{2}}$ diagram with selected phase equilibria in the system $\mathrm{CaO}-\mathrm{MgO}-\mathrm{SiO}_{2}-\mathrm{H}_{2} \mathrm{O}-\mathrm{CO}_{2}$, considering $\mathrm{SiO}_{2}$ saturation, and $\mathrm{CaO}-\mathrm{MgO}-\mathrm{SiO}_{2}$ composition diagrams illustrating mineral stability relationships in the different sectors. Modified from Bowman (1998) by using TWQ 1.02 software (Berman, 1991), with internally consistent thermodynamic data (Berman, 1988, 1990), to calculate phase equilibria for end-member mineral compositions (solid lines and invariant points $\mathrm{A}$ and $\mathrm{B}$ ), and for mineral compositions $(\mathrm{Mg} / \mathrm{Fe}$ of 0.6 ) relevant to the Riba de Alva mine skarn (dashed lines and invariant points $\mathrm{A}^{\prime}$ and $\left.\mathrm{B}^{\prime}\right) . \mathrm{Cc}=$ calcite, $\mathrm{Di}=$ diopside, $\mathrm{Do}=$ dolomite, $\mathrm{F}_{\mathrm{O}}=$ forsterite, $\mathrm{Qz}=$ quartz, $\mathrm{Tc}=$ talc, $\mathrm{Tr}=$ tremolite.

This paragenesis is very complex and needs at least $\mathrm{W}, \mathrm{Na}$, $\mathrm{Mn}, \mathrm{P}, \mathrm{B}$, and $\mathrm{Ba}$ available in the fluid, some of which could have been leached from the previously deposited skarn. The last four elements are minor components of the system since they occur in accessory ore skarn minerals.

$\mathrm{Ba}$ and $\mathrm{P}$ are absent in skarn minerals preceding the formation of armenite and apatite, so it could have come either from the host rocks, which were not investigated, or from other external origin.

Even considering the low Mn contents in pyroxenes and/or amphiboles, these minerals could be the source for $\mathrm{Mn}$ in $\mathrm{Fe}$ axinite because their abundance is greater when compared to that of $\mathrm{Fe}$ axinite.

Calcic-scapolite is commonly formed during prograde alteration or regional metamorphism at high temperatures (Beran et al., 1985; Labotka, 1991; Rebbert and Rice, 1997; Pan, 1998). Its presence in the Riba de Alva ore skarn may indicate a possible low-temperature scapolite variety or relics from a former skarn assemblage. As the Ca scapolite grains are intergrown with clinozoisite, the former hypothesis is favored and is in agreement with the reporting by Pinto (1984) of scapolite-fluorite in late hydrated assemblages in calcsilicate and skarn rocks elsewhere in the Slate Greywacke Complex.
Plagioclase is more Na rich, from bytownite in amphiboleepidote skarns to labradorite in ore skarn, than that formed during prograde alteration, reflecting an external origin for $\mathrm{Na}$ since the total amount of plagioclase in general does not decrease.

Late-stage veins with an almost monomineralic assemblage suggest cooling and dilution of the skarn system, as inferred from the presence of adularia.

According to the previous discussion, the protolith could correspond to an argillaceous dolomitic limestone, with a small argillaceous component, since the low abundance of plagioclase in the pyroxene skarn is a consequence of the minor proportion of $\mathrm{Al}$ available in the system during prograde alteration. However, in the thinner skarn extremities, where the banded amphibole-epidote skarns occur, the protolith could have been an interlayered carbonate-pelite rock (Fig. 5).

In summary, the distal strata-bound scheelite skarns from the Riba de Alva mine were formed by predominantly infiltrational metasomatism.

The presence of granite-related $\mathrm{Sn}$ and $\mathrm{Li}$ mineralizations in the vicinity of the Riba de Alva skarn, together with the high metallogenic potential of the Granitic Complex, comparable to those associated with W skarns, suggest that the 
external fluids intervening in the metasomatic process could be of magmatic origin.

\section{Comparison to Major W Skarn Deposits}

There are some systematic differences between major types of mineralized skarn systems, i.e., $\mathrm{Fe}, \mathrm{W}, \mathrm{Cu}, \mathrm{Pb}-\mathrm{Zn}$, Mo, and Sn (Einaudi et al., 1981), although many have overlapping characteristics. In addition, individual types of skarns have differences that are are mainly a function of host-rock composition, fluid composition and degree of evolution, depth of formation, intensity and paragenesis of deformation, metamorphism, and metasomatism (Meinert et al., 1980). The classic classification scheme of Einaudi et al. (1981) subdivides W skarns into "reduced" and "oxidized" types, also referred by Kwak and White (1982) as W-Sn-F and W-Mo-Cu, respectively. More recently Newberry (1998), based on the high contents of incompatible elements, has also considered W-F skarns as a distinct type subdivided into Mo-poor and Mo-rich subtypes.

The economically most important and best known $W$ skarns belong to the reduced type (e.g., Mactung and Cantung, Canada; Sandong, Korea; Salau, France; Fujigatani, Japan), containing garnet with an andradite component less than 50 mole percent, hedenbergitic pyroxene $\left(\operatorname{Hd}_{60-90}\right)$, and pyrrhotite > pyrite, as the main diagnostic features (Einaudi et al., 1981). In contrast, oxidized W skarns (e.g., King Island, Australia; Pine Creek and Strawberry, United States; Costabonne-magnesian, France) have more andraditic garnet $\left(\operatorname{Ad}_{80-100}\right)$, more salitic pyroxene $\left(\mathrm{Hd}_{20-70}\right)$, pyrite instead of pyrrhotite (Einaudi et al., 1981), and an early Mo-rich scheelite (Newberry, 1998).

The Riba de Alva skarns show several features common to the best known $W$ skarn examples in the world but also show some differences. The Riba de Alva skarns have an early stage characterized by anhydrous minerals overprinted by retrograde alteration, as is common in W skarns. However, the absence of some anhydrous minerals, such as garnet or wollastonite, as well as scheelite associated with the early skarn stage, contrast with the major W skarns.

The absence in Riba de Alva skarns of a clear, consistent mineral zoning as occurs, for example, in Sangdong (John, 1963), Cantung (Dick and Hodgson, 1982), Fujigatani (Sato, 1980), Strawberry (Nokleberg, 1981), or Salau (Zahm, 1987; Fonteilles et al., 1989) is typical of some metamorphic or magnesian skarns (Kwak, 1987) and of skarns in carbonatepoor settings.

Local thin reaction skarns with wall rocks, seen in Riba de Alva, are present in a great number of $W$ skarn deposits where calc-silicate rocks are interbedded with pelitic rocks, for example, in W skarns from western North America (Meinert et al., 1980).

The Riba de Alva skarn mineral assemblages are dominated by $\mathrm{Ca}-\mathrm{Mg}-\mathrm{Al}$ minerals, generally iron poor, such as salitic pyroxene $\left(\mathrm{Hd}_{20-40}\right)$, actinolite- $\mathrm{Mg}$ homblende, and clinozoisite. The increase in $\mathrm{Fe}$ content of minerals during skarn-forming evolution, which is typical in the majority of W skarns, e.g., Pine Creek (Newberry, 1982), Costabonne (Lummen and Verkaeren, 1986), is not seen in Riba de Alva. In fact, amphibole and pyroxene have similar $\mathrm{Mg} / \mathrm{Fe}$ ratios and clinozoisite, which occurs in all skarn facies, is systematically Fe poor.
Fe diopsidic pyroxenes are typical of metasomatic pyroxenes from oxidized tungsten skarns, as in Strawberry (Nokleberg, 1981), Pine Creek (Newberry, 1982), from Mo-poor WF skarns, as in McCullough Butte (Newberry, 1998), or from some magnesian skarns, as in Costabonne (Einaudi et al., 1981; Lummen and Verkaeren, 1986). Nevertheless, diopsidic pyroxenes are also found in facies with no garnet in Mactung and Cantung (Dick and Hodgson, 1982).

Clinozoisite, the epidote group mineral in Riba de Alva, is often seen in retrograde alteration of plagioclase or garnet in some W skarns, such as Fujigatani (Sato, 1980), Mactung (Dick and Hodgson, 1982), Pine Creek (Brown et al., 1985), or Salau (Zahm, 1987).

Metamorphism of impure carbonate rocks and diffusional exchange between unlike lithologies could also produce ironpoor calc-silicates, as suggested by Newberry (1982) for Pine Creek. The low iron content in the Riba de Alva minerals could reflect a relatively low $\mathrm{Fe}$ activity in the metasomatic fluid, which is consistent with the iron-poor peraluminous granites of the Granitic Complex.

Apatite is only an accessory mineral phase in Riba de Alva ore skarn, but fluorite is abundant, locally reaching 30 percent of the ore skarn. In many W skarns apatite and/or scheelite (e.g., Mactung and Cantung, Dick and Hodgson, 1982; Strawberry, Nokleberg, 1981) and scheelite and/or fluorite (e.g., Fujigatani, Sato, 1980; Pine Creek, Newberry, 1982; Salau, Zahm, 1987) associations are common, as well as in other types of $\mathrm{W}$ deposits where a magmatic origin is ascribed to them. Substitution of $\mathrm{F}$ for $\mathrm{OH}$ in hydrous minerals, such as amphibole and phlogopite in Riba de Alva skarns, also occurs in other W skarns, as in Salau (Zahm, 1987) and Alaskan Au-poor W skarns (Newberry et al., 1997), and reflects a high $\mathrm{F}$ activity in the metasomatic fluid.

Contrasting with minor amounts of pyrite $(<0.1 \%)$ in the Riba de Alva mine, some W skarn deposits have abundant sulfides, such as chalcopyrite (e.g., Cantung and Mactung, Dick and Hodgson, 1982), molybdenite (e.g., Sangdong, John, 1963), and pyrrhotite (in reduced type) or pyrite (in oxidized type).

Granitoids associated with both reduced and oxidized W skarns have characteristics of I-type igneous rocks, ranging from granodiorite to granite compositions (Newberry and Swanson, 1986). However, Mo-poor W-F skarns are generally associated with peraluminous S-type granites (Newberry et al., 1997; Newberry, 1998). Beyond those characteristics, all those granitoids all are highly fractionated, with water released relatively late in the crystallization history (Newberry and Swanson, 1986; Meinert, 1993), and are coarse grained, have low $\mathrm{W}$ contents, lack hydrothermal alteration, and are commonly associated with pegmatite dikes (Meinert et al., 1980; Newberry and Einaudi, 1981, Newberry and Swanson, 1986, Newberry et al., 1997, Newberry, 1998). The Granitic Complex that seems to be associated to the Riba de Alva skarns shares all these characteristics, including $W<1 \mathrm{ppm}$ and associated quartz-cassiterite veins and $\mathrm{Li}$ aplite-pegmatite dikes, and corresponds to a peraluminous S-type granite similar to those associated with Mo-poor W-F skarns.

\section{Acknowledgments}

The information presented in this manuscript comprises part of the first author's M.Sc. thesis at the Departamento de 
Geologia, Faculdade de Ciências, Universidade de Lisboa, Portugal, under the supervision of the second author. Reviews from Rainer Newberry and David Lentz, and from two Economic Geology referees helped to clarify many points, improving this manuscript significantly. Thanks are due to Daniel Oliveira and Isabel Costa for the English improvements in the manuscript.

\section{REFERENCES}

Arribas, A., 1979, Les gisements de tungstène de la zone de Morille (Province de Salamanca, Espagne): Chronique de la Recherche Minière, v. 450 , p. $27-34$ (in French).

1980, Los yaciamentos de tungsteno de la zona de Morille (Provincia de Salamanca): Boletin Geológico y minero de España, v. 91, p. 391-416 (in Spanish).

Beran, A., Göd, R., Götzinger, M., and Zemann, J., 1985, A scheelite mineralization in calc-silicate rocks of Moldanubicum (Bohemian massif) in Austria: Mineralium Deposita, v. 20, p. 16-22.

Berman, R.G., 1988, Internally-consistent thermodynamic data for stoichiometric minerals in the system $\mathrm{Na}_{2} \mathrm{O}-\mathrm{K}_{2} \mathrm{O}-\mathrm{CaO}-\mathrm{MgO}-\mathrm{FeO}-\mathrm{Fe}_{2} \mathrm{O}_{3}-\mathrm{Al}_{2} \mathrm{O}_{3}-$ $\mathrm{SiO}_{2}-\mathrm{TiO}_{2}-\mathrm{H}_{2} \mathrm{O}-\mathrm{CO}_{2}$ : Journal of Petrology, v. 29, p. 445-522.

1990, Mixing properties of $\mathrm{Ca}-\mathrm{Mg}-\mathrm{Fe}-\mathrm{Mn}$ garnets: American Mineralogist, v. 75 , p. $328-344$.

1991, Thermobarometry using multiequilibrium calculations: A new technique with petrologic applications: Canadian Mineralogist, v. 29, p. 833-855.

Bowman, J.R., 1998, Basic aspects and applications of phase equilibria in the analysis of metasomatic Ca-Mg-Al-Fe-Si skarns: Mineralogical Association of Canada Short Course Series, v. 26, p. 1-49.

Brown, P.E., Bowman, J.R., and Kelly, W.C., 1985, Petrologic and stable isotope constraints on the source and evolution of skarn-forming fluids at Pine Creek, California: ECONOMIC GEOLOGY, v. 80, p. 72-95.

Carnicero, A., 1982, Estudio del metamorfismo existente en torno al granito de Lumbrales (Salamanca): Stvdia Geológica Salamanticensia, v. 17, p. 7-20 (in Spanish).

Casquet, C., and Tornos, F., 1991, Influence of depth and igneous chemistry on ore development in skarns: the Hercynian belt of the Iberian Peninsula, in Aksyuk, A.M., Collins, L.G., Dobrovolskaya, M., Lun-Chi, H., Lowell, G.R., Lummen, G.M, Shimazaki, H., Liren, W., Zharikov, and Augusthitis, S.S., eds., Skarns, their genesis and metallogeny: Athens, Theophrastus Publications, p. 555-591.

Deer, W.A., Howie, R.A., and Zussman, J., 1992, An introduction to the rockforming minerals, 2nd ed.: Hong Kong, Longman, 696 p.

Dias, R., and Ribeiro, A., 1994, Constriction in a transpressive regime: An example in the Iberian branch of the Ibero-Armorican arc: Journal of Structural Geology, v. 16, p. 1543-1554.

Dick, L.A., and Hodgson, C.J., 1982, The MacTung W-Cu( $\mathrm{Zn})$ contact metasomatic and related deposits of the northeastern Canadian Cordillera: ECONOMIC GEOLOGY, v. 77 , p. 845-867.

Einaudi, M.T., Meinert, L.D., and Newberry, R.J., 1981, Skarn deposits: ECONOMIC GeOLOGY 75TH ANNIVERSARY Volume, p. 317-391.

El Bouseily, A.M., and El Sokkary, A.A., 1975, The relation between Rb, Ba and $\mathrm{Sr}$ in granitic rocks: Chemical Geology, v. 16, p. 207-219.

Fonteilles, M., Soler, P., Demange, M., Derré, C., Krier-Schellen, A.D., Verkaeren, J., Guy, B., and Zahm, A., 1989, The scheelite skarn deposit of Salau (Ariege, French Pyrenees): Economic Geology, v. 84, p. 1172-1209.

Garzón, J.G., and Locutura, J., 1981, The Lumbrales-Sobradillo y Villar de Ciervo-Puerto Seguro granites age determination by the Rb-Sr method: Boletin Geológico y minero de España, v. 92, p. 68-72 (in Spanish).

Gaspar, L.M., 1997, Contribution to the study of tungsten (W), tin (Sn) and lithium ( $\mathrm{Li}$ ) mineralizations in the Barca de Alva-Escalhão area, NE Portugal: Unpublished M.Sc. thesis, Portugal, University of Lisbon, 267 p. (in Portuguese; abs. in English).

Gaspar, L.M., and Inverno C.M.C., 1998a, Distal stratiform scheelite-fluorite skarns in the Riba de Alva mine, NE Portugal-mineralogy and metasomatic evolution [abs.]: Geological Association of Canada-Mineralogical Association of Canada Program with Abstracts, v. 23, p. A62-63.

1998b, P-enriched, peraluminous leucogranites in Barca de Alva-Escalhão, NE Portugal-a multi-stage anatectic complex [ext. abs.]: Prague, Univerzita Karlova, Acta Universitatis Carolinae Geologica, v. 42, p. 35-40. -1998c, The Meda-Penedono-Lumbrales Granitic Complex on the genesis of W, Sn and Li mineralizations from Barca de Alva-Escalhão area, NE Portugal [ext. abs.]: Comunicações do Instituto Geológico e mineiro, v. 84 , p. B63-B66.

Grew, E.S., 1996, Borosilicates (exclusive of tourmaline) and boron in rockforming minerals in metamorphic environments: Reviews in Mineralogy, $\mathrm{v}$. 33 , p. 387-502.

Guidotti, C.V., 1984, Micas in metamorphic rocks: Reviews in Mineralogy, v. 13, p. $357-468$.

Hallestein, C.P., and Pederson, J.L., 1983, Scheelite mineralization in Central East Greenland: Mineralium Deposita, v. 18, p. 315-333.

John, Y.W., 1963, Geology and origin of Sangdong tungsten mine, Republic of Korea: ECONOMIC GEOLOGY, v. 58, p. 1285-1300.

Kwak, T.A.P., 1987, W-Sn skarns deposits and related metamorphic skarns and granitoids: Developments in Economic Geology, v. 24, 451 p.

Kwak, T.A.P., and Tan, T.H., 1981, The geochemistry of zoning in skarn minerals at the King Island (Dolphin) mine: ECONOMIC GEOLOGY, v. 76, p. 468-497.

Kwak, T.A.P., and White A.J.R., 1982, Contrasting W-Mo-Cu and W-Sn-F skarn types and related granitoids: Mining Geology, v. 32, p. 339-351.

Labotka, T.C, 1991, Chemical and physical properties of fluids: Reviews in Mineralogy, v. 26, p. 43-104.

Larsen, R.B., 1991, Tungsten skarn mineralization in regional metamorphic terrain in northern Norway: A possible metamorphic ore deposit: Mineralium Deposita, v. 26, p. 281-289.

Leake, B.E., 1978, Nomenclature of amphiboles: Mineralogical Magazine, v. 42, p. 533-563.

López-Plaza, M., Carnicero, A., Gonzalo, J.C., 1982, Estudio Geológico del campo filoneano de La Fregeneda (Salamanca): Stvdia Geológica Salamanticensia, v. 17 , p. 89-98 (in Spanish).

Lummen, G.M., and Verkaeren, J., 1986, Physicochemical study of skarn formation in pelitic rock, Costabonne peak area, eastern Pyrenees, France: Contributions to Mineralogy and Petrology, v. 93, p. 77-88.

Mangas, J., and Arribas, A., 1988, Evolution of hydrothermal fluids in the Feli tin deposit, western Spain: Bulletin de Minéralogie, v. 111, p. 343358.

Mason, B., 1987, Armenite from Broken Hill, Australia, with comments on calciocelsian and barium anorthite: Mineralogical Magazine, v. 51, p. 317-318.

Meinert, L.D., 1992, Skarn and skarn deposits: Geoscience Canada, v. 19, p. $145-162$

1993, Igneous petrogenesis and skarn deposits: Geological Association of Canada Special Paper 40, p. 569-583.

- 1995, Composition variation of igneous rocks associated with skarn deposits-chemical evidence for a genetic connection between petrogenesis and mineralization: Mineralogical Association of Canada Short Course Series, v. 23 , p. $401-418$.

Meinert, L.D., Newberry, R.J., and Einaudi, M.T., 1980, An overview of tungsten, copper, and zinc-bearing skarns in western North America: U.S. Geological Survey Open-File Report 81-355, p. 304-327.

METAMERQUE, 1976, Geological characteristics of Riba de Alva deposit, Portugal: Porto, Portugal, Report to the Circunscrição mineira do Norte, Ministério da Indústria, 11 p. (in Portuguese).

Morimoto, N., Fabries, J., Fergunson, A.K., Ginzburg, I.V., Ross, M., Seifert, F.A., Zussman, J., Aoki, K., and Gottardi, G., 1988, Nomenclature of pyroxenes: American Mineralogist, v. 73, p. 1123-1133.

Newberry, R.J., 1982, Tungsten-bearing skarns of the Sierra Nevada. I. The Pine Creek mine, California: EConomic Geology, v. 77, p. 823-844.

1998, W- and Sn-skarns deposits: A 1998 status report: Mineralogical Association of Canada Short Course Series, v. 26, p. 289-335.

Newberry, R.J., and Einaudi, M.T., 1981, Tectonic and geochemical setting of tungsten skarn mineralization in the Cordillera: Arizona Geological Society Digest, v. 14, p. 99-111.

Newberry, R.J., and Swanson, S.E., 1986, Scheelite skarn granitoids: An evaluation of the roles of magmatic source and process: Ore Geology Reviews, v. 1, p. $57-81$.

Newberry, R.J., Allegro, G.L., Cutler, S.E., Hagen-Levelle, J.H., Adams, D.D., Nicholson, L.C., Weglarz, T.B., Bakke, A.A., Clautice, K.H., Coulter, G.A., Ford, M.J., Myers, G.L., and Szumigala, D.J., 1997, Skarn deposits of Alaska: Economic Geology Monograph 9, p. 355-395.

Nokleberg, W.J., 1981, Geologic setting, petrology, and geochemistry of zoned tungsten-bearing skarns at the Strawberry mine, central Sierra Nevada, California: ECONOMIC Geology v. 76, p. 111-133. 
Pan, Y., 1998, Scapolite in skarn deposits: Petrogenetic and geochemical significance: Mineralogical Association of Canada Short Course Series, v. 26, p. $169-209$.

Pellitero, E., Saavedra, J., Sanchez, A.G., and Gonzalo, F., 1985, Caracterizacion de concentraciones estratiformes de Sn y W en la zona de San Pedro de Rozados-Martinamor (Salamanca): Cuademos do Laboratório Xeolóxico de Laxe, v. 9, p. 177-189 (in Spanish).

Pinto, A.F.F., 1984, Calc-silicate rocks from the Slate-Greywacke Complex: Mineralogy, geochemistry, genetic evolution: Comunicações dos Serviços Geológicos de Portugal, v. 70, p. 55-62 (in Portuguese; abs. in English).

1985, Trace-element geochemistry of calc-silicate rocks from northern and central Portugal: Comunicações dos Serviços Geológicos de Portugal, v. 71, p. $187-1.96$

Raith, J.G., 1990, Strata-bound scheelite in metacarbonate rocks-example from Lower Austroalpine Klamm Alm mineralization, Navis, Tyrol, Austria: Institution of Minning and Metallurgy Transactions, v. 99, p. B81-B90.

-1991, Stratabound tungsten mineralization in regional metamorphic calc-silicate rocks from the Austroalpine Crystalline Complex, Austria: Mineralium Deposita, v. 26, p. 72-80

Ray, G.E., Webster, I.C.L., and Etlinger, A.D., 1995, The distribution of skarns in British Columbia and the chemistry and ages of their related plutonic rocks: ECONOMIC GEOLOGY, v. 90, p. 920-937.

Rebbert, C.R., and Rice, J.M., 1997, Scapolite-plagioclase exchange: $\mathrm{Cl}-\mathrm{CO}_{3}$ scapolite solution chemistry and implications for peristerite plagioclase: Geochimica et Cosmochimica Acta, v. 61, p. 555-567.

Ribeiro, A., and Pereira, E., 1982, Paleogeographical, petrological and structural controls on the genesis of the Portuguese tin and tungsten deposits: Lisboa, Geonovas, v. 3, p. 23-30 (in Portuguese; abs. in English)

Robinson, P., Spear, F.S., Schumacher, J.C., Laird, J., Klein, C., Evans, B.W., and Doolan, B.L., 1982, Phase relations of metamorphic amphiboles: Natural occurrence: Reviews in Mineralogy, v. 9B, p. 1-228.

Roda, E.R., Pesquera, A.P., and Velasco, F.R., 1991, The pegmatites of the Fregeneda area, Salamanca, Spain, in Pagel, M., and Leroy, J.L., eds., Source, transport and deposition of metals: Rotterdam, Balkema, p. 801-806.

Roda, E.R., Fontan, F., Pesquera, A., and Velasco, F.R., 1995, Mineralogical and geochemical evidence for pegmatites formation: The Fregeneda pegmatitic field, Salamanca, Spain, in Pasava, J., Kribek, B., Zak, K., eds., Mineral deposits: From their origin to environmental impacts: Rotterdam, Balkema, p. 505-509.
Rosenberg, P.E., and Foit, F.F., Jr., 1977, $\mathrm{Fe}^{2+}-\mathrm{F}$ avoidance in silicates: Geochimica et Cosmochimica Acta, v. 41, p. 345-346.

Sato, K., 1980, Tungsten skarn deposit of the Fujigatani mine, Southwest Japan: ECONOMIC GEOLOGY, v. 75, p. 1066-1082.

Schermerhorn, L.J.G., 1982, Framework and evolution of Hercynian mineralization in the Iberian Meseta: Comunicações dos Serviços Geológicos de Portugal, v. 68, p. 91-140.

Silva, A.F., and Ribeiro, M.L., 1994, Explanatory notes of sheet 15-B (Freixo de Espada à Cinta), geological map of Portugal, scale 1:50,000: Lisboa, Instituto Geológico e mineiro de Portugal, $48 \mathrm{p}$. (in Portuguese).

Silva, A.F., Santos, A.J., Ribeiro, A., Cabral, J., and Ribeiro, M.L., 1990 , Sheet 15-B (Freixo de Espada à Cinta), geological map of Portugal, scale 1:50,000: Lisboa, Serviços Geológicos de Portugal.

Skaarup, P., 1974, Strata-bound scheelite mineralization in skarns and gneisses from the Bindal area, northern Norway: Mineralium Deposita, $v$. 9, p. 299-308.

Sousa, M.B., 1983, Lithostratigraphy of the Slate-Greywacke ComplexDouro Group (NE Portugal): Memórias e Notícias, Publicações do Museu e Laboratório mineralógico e Geológico da Universidade de Coimbra, Portugal, v. 95 , p. 3-63.

Tischendorf, 1977, Geochemical and petrographic characteristics of silicic magmatic rocks associated witl rare-element mineralization: IGCP Symposium Mineralization Associated with Acid Magmatism (MAWAM), Karlovy Vary, Czech Republic, October 1974, Proceedings, v. 2(3), p. 41-96.

Turner, F.J., 1981, Metamorphic petrology: Mineralogical, field, and tectonic aspects, $2^{\text {nd }}$ ed.: Washington, DC, Hemisphere Publishing, 524 p.

Viegas, L., 1983, Tungsten and tin mineral resources in Freixo-Escalhão region: Porto, Internal report of the Serviço de Fomento mineiro, 45 p. (in Portuguese).

Zahm, A., 1987, The compositional evolution of calc silicates from Salau skarn deposit (Ariége, Pyrénées): Bulletin de Minéralogie, v. 110, p $623-632$.

Zaw, U.K., and Clark, A.H., 1978, Fluoride-hydroxyl ratios of skam silicates, Cantung E-zone scheelite orebody, Tungsten, Northwest Territories: Canadian Mineralogist, v. 16, p. 207-221. 